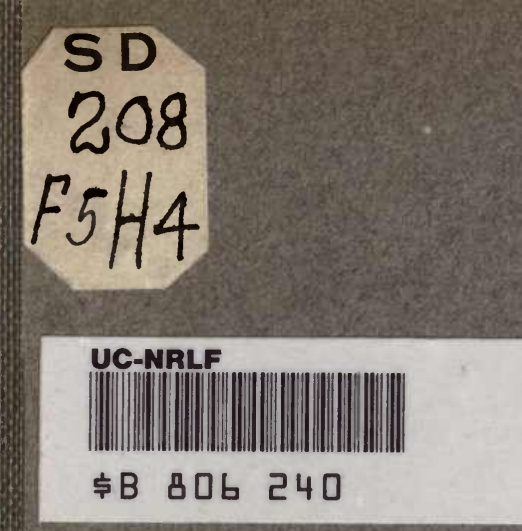




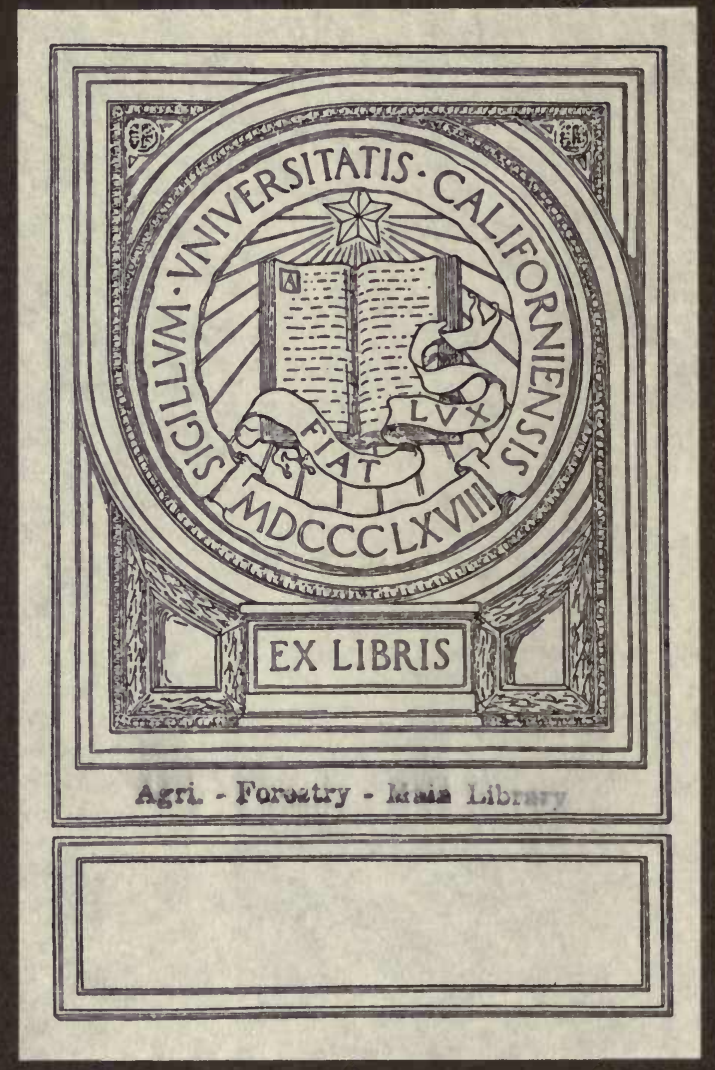




\section{FORESTRY IN FINLAND}

WRITTEN BY

OLLI HEIKINHEIMO AND EINO SAARI

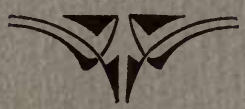





\section{FORESTRY IN FINLAND}

WRITTEN BY

OLLI HEIKINHEIMO AND EINO SAARI

1

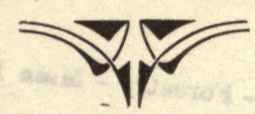

HELSINKI (HELSINGFORS), 1922

GOVERNMENT PRINTING-OFFICE 


$$
\begin{aligned}
& \text { Agri. - Forentry - his wa Library } \\
& \because \because \because \quad \vdots \because \vdots \vdots \vdots \vdots \vdots \\
& \therefore \because \because \because \because \because \vdots \vdots \vdots \cdots \cdots
\end{aligned}
$$


Of the following pages, the former half, pages $1-20$, was written by the undersigned Olli Heikinheimo, the latter half, pages 21-42, by the undersigned Eino Saari.

Helsinki (Helsingfors), June 3 rd 1922.

Olli Heikinheimo.

Eino Saari. 


\section{CONTENTS.}

Extent of the Forests..................................... 1

Nature of the Forest Lands................................. 4

Nature of the Forests..................................... 7

Forest Management Areas. ................................ 14

The Proportion of Ownership of Land and Forest................. 20

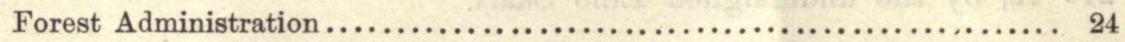

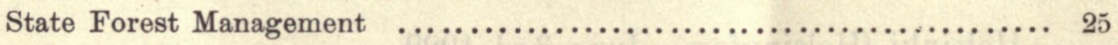

Communal and Private Forests and Their Management $\ldots \ldots \ldots \ldots \ldots \ldots . .31$

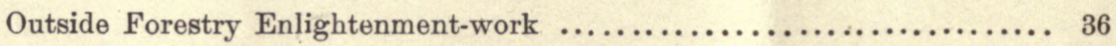

Education in Forestry and Scientific Investigation................. 38

The Significance of the Forests for Finlands Industries and the Trade Balance 40 


\section{Extent of the Forests.}

According to existing statistics, which are doubtlessly in many respects in need of revision, the forest-clad portion of Finland has a total area of 20.5 million hectares, covering thus about $60 \%$ of the total land area of the country. According to the foregoing, Finland is relatively richer in forest than any other land in Europe, and third in order if the absolute area of forest be taken into account.

In earlier times, the forest area has been much greater than it is now. In fact, the area that never, at any time, has been covered by forest is exceedingly small. The most decisive factors in the decrease in the forest-area have been the formation of swamps and the spread of settling with the inevitably following cultivation of land.

The extent of the existing bogs or swamps is about 10.5 million hectares, really slightly more, if the thinly turfed marshy lands be included. Of this enormous area, the overwhelmingly great majority has formerly been forest land, which has now, after the formation of the marshes, become either altogether forestless or at least degenerated from its former growth. Thus the investigations carried out in Central Pohjanmaa (Österbotten) have shown that of the great marsh lands there, about $95 \%$ have usurped the place of former forests and only $5 \%$ have been formed by the gradual drying-up of former lakes. Entirely forestless swamps form here, as also in North Finland, on an average about one third of the whole swamp areas, while in South Finland the portion taken up by them is generally much smaller. Even the forest-growing swamps cannot, however, in many cases, be reckoned as true forest, the possibilities for forest to thrive being often very small. In any case, the former forest lands that have become useless for forest-growing can be calculated at 4-5 million hectares, of which the greater part is situated in the Administrative District of Oulu (Uleåborg), where in the wide $a a p a$-marsh areas even $50-60 \%$ of the total land area can be taken up by marshes.

The cultivated lands, also, of which there are now slightly over 2 million hectares in Finland, have originally been wrung from the forests. Without doubt, many of the present hard soil fields have 
formerly been prepared for cultivation by burning - a method of clearing ground for fields formerly much used in Finland ${ }^{1}$ ) - which naturally presupposes their former covering of forest. Similarly, the greater part of the cultivated marsh-lands are on the sites of former forests. According to investigations in the Administrative Districts of Kuopio, Mikkeli (St. Michel) and Viipuri (Viborg), about $80 \%$ of the land now cultivated has earlier been forest and about $20 \%$ marsh land, of which only about $13 \%$ has been forestless. The richer a neighbourhood has been in arable land, the more quickly and thickly has it become populated, the areas of growing forest diminishing accordingly.

What has been said in the foregoing regarding cultivated land applies chiefly also to the so-called natural pasture-lands, which according to an estimate made of them take up close on 1 million hectares. These have also earlier been the best-growing forest land of their respective districts, and even now it is not at all unusual to find quite a goodly number of trees on them.

Still closer to the forests proper are the "haka» pasturages, which for this reason have also been included in the aforementioned 20.5 million hectares of growing forest. Their extent was adjudged in the statistics collected by the Board of Agriculture in 1920, to be about 0.63 million hectares. If the term "haka" pasturage be widened to include other than smaller cattle-pasturages enclosed within fences, as was done in the said statistics, e. g., all forest areas where the forest itself has acquired the nature of "haka» forest on account of cattle being allowed to graze there, this area will be considerably increased, perhaps to about 2 million hectares, or nearly $10 \%$ of the whole area of forests. In the earlier-mentioned Administrative Districts of Kuopio, Mikkeli (St. Michel) and Viipuri (Viborg), forests of this description formed, according to certain investigations, about $31 \%$ of the total forests. In other districts where clearing by burning has not been so common lately, the proportion of "haka" forests is smaller.

Naturally forestless areas are for the most part rocky ground and naked rock, above all the parts of Lapland north of the forestline, and even further south, the mountainous ridges and the naked roofs of solitary fells. On the former, the thriving of any forest is impossible on account of the nature of the ground, on the latter, at-

1) The metbod in question is as follows: During the summer previous to the burning, the forest is cut down, the trees being left on the site. In the burning, the undergrowth and the branches and tops of the trees disappear, the larger trunks are conveyed elsewhere and the land is then ready for cultivation. Atter the lapse of a few years, forest is allowed to grow again on the clearing. 
mospheric conditions, mainly the low temperature during the season of growth, make the matter equally difficult. The figure (1), dealing in detail with the northern districts of Finland around the

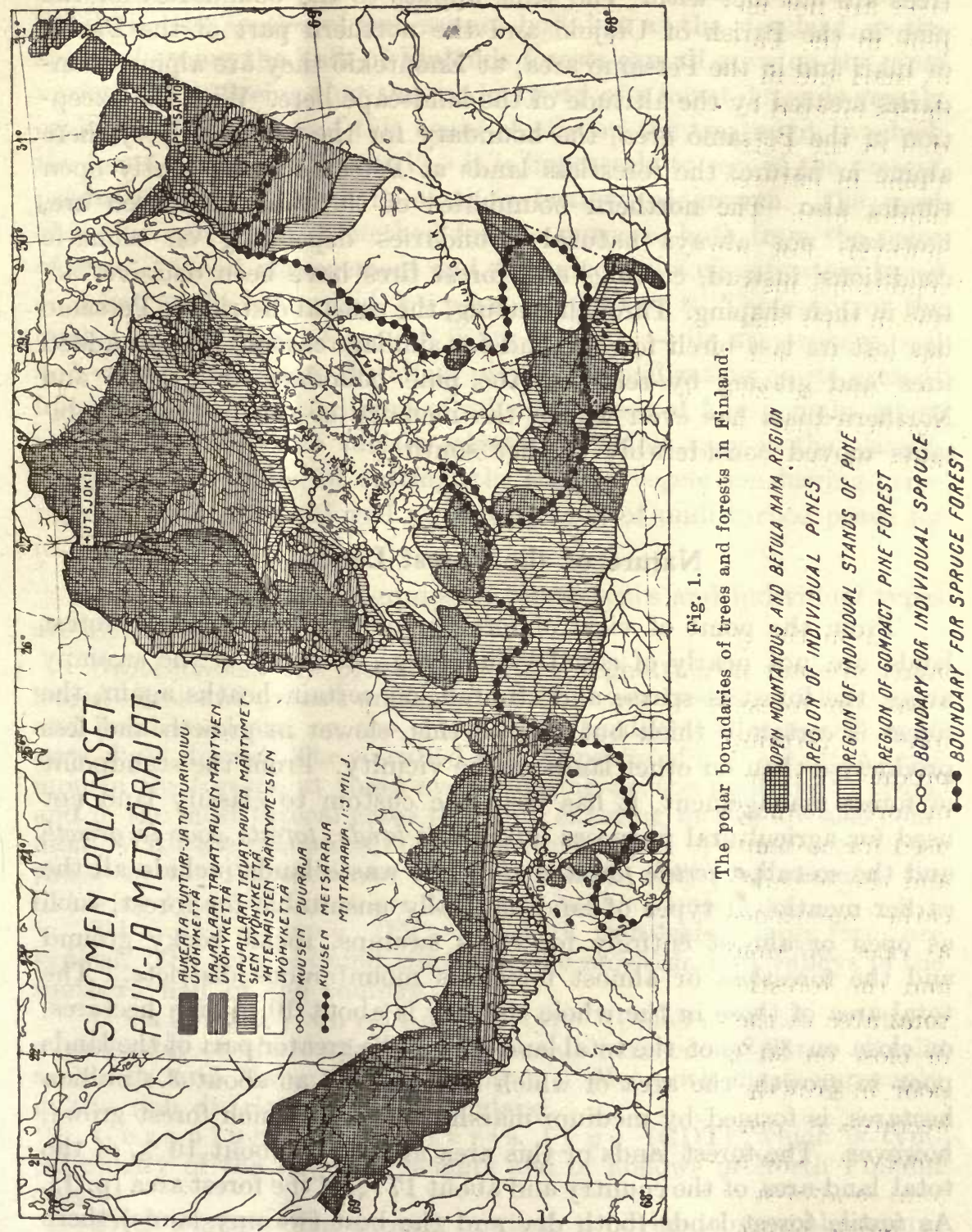

forest-lines, shows the forestless, mountainous areas in Far Lapland to cover an area of about 2 million hectares, and all areas where the pine cannot form consecutive forest, about 4 million hectares. All the districts shaded by lines in the diagram are such where the birch is the prevailing tree; coniferous trees are met with only in more 
favourable circumstances. The northern boundaries for the spruce shown in the diagram are true northern boundaries, as north of the longitude of this part of Finland, spruce forests or individual sprucetrees are not met with. The same applies to the boundaries for the pine in the Parish of Utsjoki and the northern part of the Parish of Inari and in the Petsamo area; at Enontekiö they are alpine boundaries created by the altitude of the landscape here. With the exception of the Petsamo area, the boundary for the birch is everywhere alpine in nature, the forestless lands at Petsamo being partly open tundra also. The northern boundaries of the pine and birch are, however, not always natural boundaries depending on climatic conditions, instead, cuttings and forest fires have been decisive factors in their shaping. Through cutting, the coastal district at Petsamo has lost its last birch forests, and for similar reasons, thereto added fires and grazing by reindeer, the pine boundary at Utsjoki and Northern-Inari has even within the memory of the present inhabitants moved considerably further south.

\section{Nature of the Forest Lands.}

From the point of view of fertility of forest growth the forest lands are not nearly of equal value. E.g., in many of the swampy areas, the forest is sparse and stunted, on certain heaths again, the forest is certainly thick but despite this, slower in growth and less productive than on other lands in the vicinity. From the standpoint of forest management, it has been the custom to classify land not used for agricultural purposes into waste lands, forests poor in growth and the so-called fertile forest-lands. The waste lands include all the earlier mentioned types of land naturally unsuitable for forest, such as open or almost entirely forestless swamps, rocks, rocky ground and the forestless or almost forestless mountainous districts. The total area of these in the whole country is about 10 million hectares, or close on $30 \%$ of the total land-area. The greater part of the lands poor in growth, the area of which is estimated at about 3.5 million hectares, is formed by medium marshy lands on which forest grows, however. The forest lands of this area answer to about $10 \%$ of the total land-area of the country and about $17 \%$ of the forest area (p. 1). As fertile forest lands (both dry and the best swampy lands) there are thus left about 17 million hectares of land, of which in the foregoing, about 2 million hectares were estimated as "haka» forest. The area on which the forest economy of Finland is chiefly based, is thus about 15 million hectares, corresponding to $71 \%$ of the total area of forest land and about $44 \%$ of the total land-area of the country. 
The fertile forest lands also may be divided into different grades. As a base for this classification, a mere grouping according to the soil is unsuited, as, e.g., on glacial drift both the best and the least productive grades of forests are found, depending on the circumstances. Similarly, the species of tree cannot be taken as the standard, as the species forming the bulk of Finlands forests can all grow on the most various sites. Seeing that the productivity of a forest depends greatly on its condition - and this again chiefly on the treatment to which the forest has been subjected - it is impossible to regard the present productivity as a measure of their fertility of growth. The most objective and the best method for the purpose, both from the point of view of forest management and silviculture is a classification based on what might be termed $t y p e s$ of $f$ or es $t$. These mirror the quality of the place of growth in its entirety - its atmosphere, soil and even in some part the effect played by civilization on its present formation. In the classifying of different types of forest, main attention is directed to its surface vegetation. Most easy is the classification of forest ripe for cutting, the surface vegetation having generally in such cases enjoyed a longer period of undisturbed peace for its development.

The most important groups of forest-types and individual types are the following:

Grove-forests. The prevailing surface vegetation in these is thinleafed herbs and grasses and many of the rarer bushes. Lichen, moss and brushwood are, on the other hand, hardly at all met with, or in very slight degree. The so-called nobler species of tree are often common in the forests, at times even building up the majority in them, and in the most typical cases the more exacting bushes are also common. With the exception of certain local types of small area (e. g., those on the Ahvenanmaa (Åland) Islands and at Sortavala) the following types of forest are included in this same class.

The fern-t y p e (FT), of which thin-leafed, large ferns are typical. The type is found chiefly in the moistish, rich valleys of the southern half of the country.

O x a li s-M a j a n th e m u m type (OMaT), which contains a profusion of thin-leafed, chiefly small herbaceous plants (Oxalis acetosella and Majanthemum bifolium). Met with most commonly in the rich districts of South Finland.

Geranium -Dryopteris type (GDT), which is typical chiefly of the slopes of heights and of hollows in North Finland only.

Fresh Forests. The ground in these is covered by an almost unbroken carpet of mosses and plentiful blueberry bushes. Almost all of the ordinary forest-trees are met with here as forest-forming; the so-called nobler trees are lacking or only rarely met with in these forests. The following types compose this group.

Oxalis-Myrtillus type (OMT), in which, side by side with blueberry bushes and the more exacting mosses, thin-leafed 
Oxalis, etc., is found. Appears fairly commonly in South and Central Finland.

Myrtillus t y p e (MT) typical of which are the blueberry and certain Hylocomium, Dicranum and Ptilium species. The predominating forest-type on the moraine-formations of the southern half of Finland.

Hylocomium-Myrtillus type (HMT), in which blueberry bushes and especially the Hylocomium mosses are more luxuriant than in the former, and the vegetation is also otherwise slightly different from that in the foregoing. This is a North Finnish type, met with most often on wider ridges and heights.

Heath forests. The surface vegetation is here typical dry land vegetation, such as lichen, Vaccinium vitis idaea, Calluna vulgaris and Empetrum nigrum. These forests, in which the pine is nearly always predominant, are generally divided into the following types.

Vace nium type (VT) typical of which is the Vaccinium vitis idaea. It is met with fairly far north also, but is more common on the ridges in the southern half of the land.

C. a 11 una ty pe (CT) in which Calluna vulgaris is plentiful. Common on the sandy lands in the southern half of the country.

E m petru m-M y r i 11 u s t y p e (EMT), the most characteristic feature of which are the plants mentioned. Met with only on dry heaths of a "fresh" nature.

Myrtillus-Cladina type (MClT), fairly common on the dryer heaths in North Finland.

Cladina ty p e (ClT), the surface vegetation of which is almost solely lichen. Commonest on the dry sandy lands of North Finland.

The varying productivity of the different types of forest and the difference in value imposed by the same is shown by the following figures taken from yield-tables drawn up for the different forest-types of the forests in South Finland, which show the amount of growing stock (minus bark) per hectare of eighty-year forests of equal age.

$\begin{array}{cccc}\text { Forest-type } & \begin{array}{c}\text { Pine forest } \\ \text { (Pinus sil- } \\ \text { vestris) }\end{array} & \begin{array}{c}\text { Spruce } \\ \text { forest } \\ \text { (Picea ex } \\ \text { celsa) }\end{array} & \text { Birch forest } \\ \text { Betula }\end{array}$

Oxalis-Majanth. type .

Oxalis-Myrtillus type.

Myrtillus type ........

Vaccinium type .......

Calluna type ....... 146

Cladina type $\ldots \ldots \ldots 61$

407 cub.metr. 367 cub.metr. 243

359 " 320 "

258 " - 군

61 "

Similarly illustrative figures are obtained if the variations in the number of larger trees on the different areas be examined. Thus, the number of pines filling at least 20 centimetres at a height of $1.3 \mathrm{~m}$ in one hectare of 80 year old forest is: 573 in the Oxalis-Myrtillus type, 548 in the Myrtillus type, 378 in the Vaccinium type and 71 in the Calluna type. 
As shown by the list of forest-types, both the appearance and the comparative prevalence of the forest-types varies considerably in different parts of the country. This is further shown by the following figures which are based on the results of valuation-surveys by line carried out at different times, the rarer forest-types being included in the nearest general type.

\begin{tabular}{|c|c|c|}
\hline Forest-type & $\begin{array}{l}\text { Savo and } \\
\text { Carelia }\end{array}$ & $\begin{array}{l}\text { Parish of Kuh- } \\
\text { malahti in Cen- } \\
\text { tral Finland }\end{array}$ \\
\hline
\end{tabular}
Oxalis-Majanthemum type ......
Oxalis-Myrtillus type ........ 32.02 "
Myrtillus type...
$28.62 "$
Vaccinium type
$29.74 "$
Calluna type
3.07 "
Geranium-Dryopteris type ......

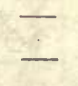
Hylocomium-Myrtillus type $\ldots .$.
Cladina type

$\begin{array}{rr}- & - \\ 11.36 \% & - \\ 49.28 " & 9.24 \% \\ 27.67 " & 5.68 " \\ 11.69 " & 8.53 " \\ - & 3.37 " \\ - & 19.18 " \\ - & 18.12 " \\ - & 35.88 "\end{array}$

Thus, the further north one comes, the rarer are the best foresttypes, and in North Finland the predominating types are such as are never or only nominally met with in the southern part of the land. In this connection the existence of the different forest-types is a key to the reasons for the difference in productivity between the various parts of the country. The proportion of appearance and prevalence of the forest-types varies, however, even in the same district, depending, among other reasons, on the degree of lime in the soil, partly also in the bed-rock, the situation of the land at different heights, whether on the watersheds or near larger waters, and finally, on the varying soils, etc., etc. In the grove-forest areas, of which more is spoken in the part on forest management areas, the soil is usually comparatively rich in lime.

\section{Nature of the Forests.}

The composition of Finland's forests with regard to the different species of trees is affected by the geographical distribution of the various species and their relation to the many forest-types, and the results of civilization, such as cutting and fires. The former factor is of small importance elsewhere than in Lapland; where the boundaries of the two most common trees in the forests of Finland the pine (Pinus silvestris) and the spruce (Picea excelsa) are situated comparatively far apart (Fig. 1). Of the commoner forest trees Betula odorata species of birch, the aspen (Populus tremula) and 
Alnus incana are found furthest north. Betula verrucosa, on the other hand, ceases to grow even further south than the pine and Alnus glutinosa, which on its part fails to achieve the Arctic Circle. The northern boundary of this and of the nobler trees: the oak, ash, maple, linden, elm and hazel-bush is shown in Fig. 2. As all the latter species are fairly rare even in the southern parts of the country, their economic significance is for the present very small.

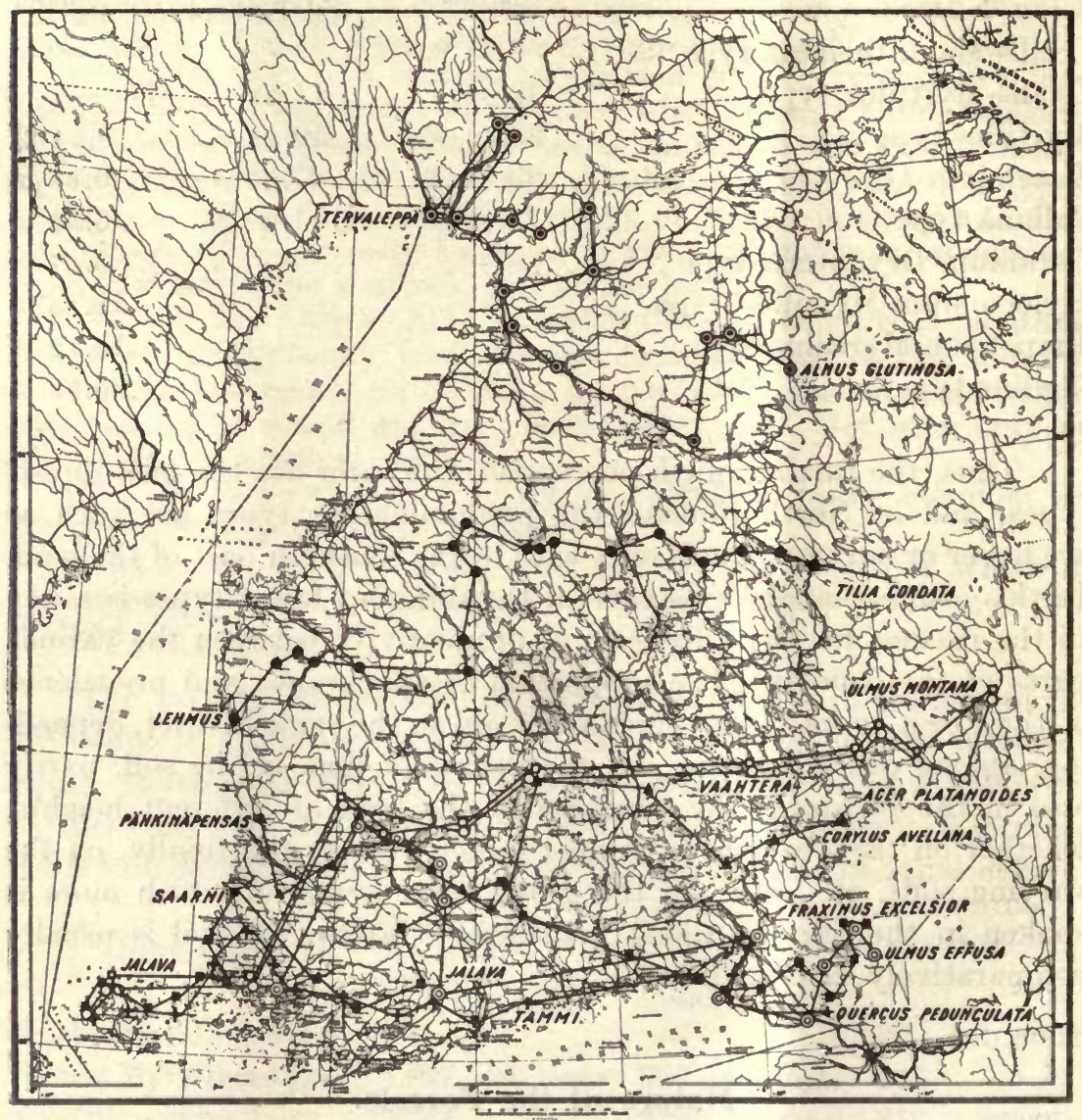

Fig. 2. Norther boundaries of various trees.

Of the various forest-types all others are naturally suited for the pine except the Hylocomium-Myrtillus type of North Finland and the most fertile grove-forest types, in which the natural regeneration of the pine is difficult. In the heath forests, hardly any other tree can thrive and the pine is therefore of its nature the predominant tree in these. A similar condition prevails in the vräme»-swamps, where, beside the pine, chiefly Betula odorata is met with. Suited to the spruce are all the fresh forest-types and 1 korpii-swamps, and also the grove-forests, although the regeneration of the spruce in the latter 
is open to doubt, so that the most typical grove-forests comprise, also for this reason, chiefly leaf-trees, which have the power of propagation also by shoots. Of the different species of birch, the B. odorata is more suited to moistish sites and Betula verrucosa to dryer ground.

In the fresh forest-types, fires and cultivation by burning have assisted the spreading of the pine and hindered that of the spruce. As an extremely great part of the forests of North Finland in particular have either sprung up after fires or been in touch with the latter afterwards, it is plain that this matter has greatly influenced the present distribution of the various species of tree. Cultivation by previous burning, which for the last fifty years has, particularly in the eastern portion of the land, been in use as far north as the southern part of the Parish of Kuolajärvi (up to the Arctic Circle), has had varying effects, generally however such that the pine and leaf-trees have become commoner at the expense of the spruce. Where this method of cultivation has been more widespread, as in certain parishes in Savo, in which as much as $75 \%$ of the solid forest lands have once been burned over, the spruce has become fairly rare. A renewal of the burnings after the lapse of as short a period as 20 years has had as result that even the pine has not had time to regenerate, but instead, the forests have gradually become covered with stands of birch and Alnus incana.

With a view to the fact that only a comparatively small portion of the cuttings carried out in Finland have been actual regeneration cuttings from the standpoint of actual forestry, the spruce has on the other hand become more common by reason of these cuttings than would otherwise have been possible. All cuttings in which only certain species of trees are taken (cuttings of trees for pulp-wood, pitprops, bobbins, the barking of trees for resinous wood, etc.,) have naturally affected in their own manner the composition of the forests.

On the basis of the foregoing it is possible to explain the following results, which show the comparative prevalence of different species of trees in the various parts of the country and in the forests of different proprietors. The species of forest (in smaller areas) is decided by the predominating tree and the figures given are for fertile forest land.

$\begin{array}{cccc}\text { Species of tree } & \begin{array}{c}\text { State } \\ \text { forests }\end{array} & \begin{array}{c}\text { Point } \text { Stock } \\ \text { Co. forests } \\ \text { in Savo }\end{array} & \begin{array}{c}\text { Forest in } \\ \text { Savo and } \\ \text { Carelia } \\ \text { average }\end{array}\end{array}$

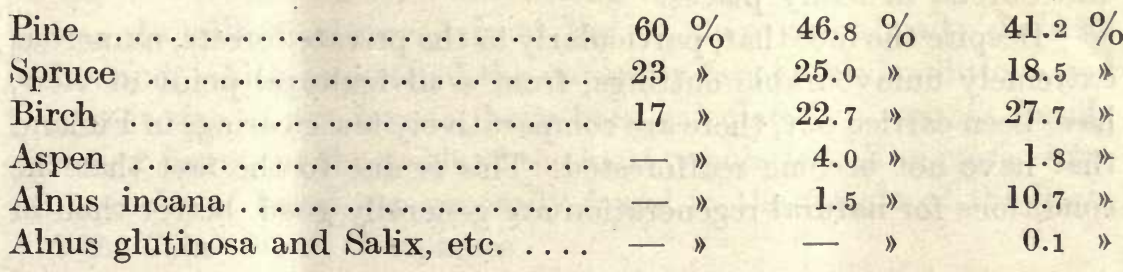


There can hardly be room for any greater error if the proportion covered by pine in the total area of the forests of the country be put down at $50 \%$, that of the spruce at. $25 \%$, the birch at $20 \%$ and the other trees at about $5 \%$.

The conditions of age of the forests are not nearly normal in Finland, as will be seen from the following figures, which show the proportion of area of the different classes of age in the fertile forests. The statistics for the State forests concern only coniferous forests, those for the Joint Stock Company lands chiefly coniferous forests and those for the private forests only pine forests, so that the differences in the forests of the various classes of owner depend partly on this circumstance.

\begin{tabular}{|c|c|c|c|c|c|}
\hline Age & & & $\begin{array}{c}\text { State forests } \\
\text { in the Kemi } \\
\text { inspection } \\
\text { in North } \\
\text { Finland }\end{array}$ & $\begin{array}{l}\text { Mainly Com- } \\
\text { pany forests } \\
\text { in Central } \\
\text { and South } \\
\text { Finland }\end{array}$ & $\begin{array}{l}\text { Private for- } \\
\text { ests in Savo } \\
\text { and Carelia }\end{array}$ \\
\hline $1-15$ & ears & . & $5.2 \%$ & & \\
\hline $51-100$ & ") & $\ldots \ldots \ldots$ & 10.5 & 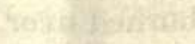 & \\
\hline $101-150$ & $》$ & & 26.8 & & \\
\hline $151-200$ & " & $\ldots$ & $29.8 \|$ & & \\
\hline over 200 & 》 & & 27.7 & & \\
\hline $1-20$ & $"$ & & & $6.3 \%$ & $13.0 \%$ \\
\hline $21-40$ & $"$ & $\ldots$ & 1 & $21.6 "$ & $31.1 》$ \\
\hline $41-60$ & ॥ & $\ldots$ & & 29.1 & 24.8 \\
\hline $61-80$ & " & & & $26.9 \gg$ & 18.8 \\
\hline $81-100$ & " & & & $9.4 \gg$ & $10.0 \Rightarrow$ \\
\hline ver 100 & 》) & & & $6.7 \gg$ & 2.3 \\
\hline
\end{tabular}

Comparatively least represented in all the forests is the youngest class. Specially great is the difference in the quantities of the older and the younger classes in the State forests of North Finland.

The condition of forest described in the foregoing is due to the fact that true regeneration cuttings have not been carried out in the degree needed. Up to quite recent times the State forests have also contained comparatively many old, untouched natural forests, in which the younger classes can have sprung up only after forest fires. These fires, and before all the method of cultivation by burning, are the chief reasons for the comparative youth of the forests of Savo and Carelia in many places.

Despite the fact that, particularly in the private forests, numerous extremely unfavourable cuttings, from a silvicultural point of view, have been carried out, there are comparatively few clearings in Finland that have not become reafforested. This is due to the fact that the conditions for natural regeneration are generally good, better than in 
most other European countries. Seed-productivity is plentiful among the forest-trees: in Central and South Finland 2-3 abundant seedyears occur for the pine and the spruce in each decade, the quality of seed being good in both cases. The birch and the alder give good seed almost every year, but of these a comparatively greater part is wasted than in the case of coniferous trees, whose seed germinates more easily in the fresh spring soil and is less easily prevented by the undergrowth of the commoner forest-types from reaching the ground and developing. In unfavourable circumstances the regeneration of leaf-trees occurs chiefly through new shoots, the facility with which the latter are born helping even such forests as are used for pasturage from declining all too much.

The regeneration of forests is appreciably more difficult in North Finland. Here the better seed-years for the pine and the spruce recur only on an average each tenth year, and even then the seedproductivity is only a small portion of that further south. In addition, the young plants suffer from drought in the prevailing heath-forests and perish easily in the struggle among themselves and especially with the older trees for the meagre sustenance of the soil. On account of the scant regeneration, even the pine forests are often of different ages, in the sense that trees and plants are met with in them from several different regeneration years. On the northern boundary of the pine the rarity of regeneration years has a still greater effect on the proportion of different ages among the trees and forests. Here a regeneration year can occur on an average only each century: the northern pines date from about the years $1850,1760,1650$ or 1575.

Owing to the unfavourable density of crop of the forests, the growing stock and the yield of the forests are not nearly as favourable as would be expected from the proportion of ageclasses. In the majority of cases, especially among the private forests, the unproductive area can be reckoned, owing to the sparseness the forest, in tens per cent, the growing stock and yield being at the least in a corresponding degree below normal. Together with an unfav ourable proportion among the different species of trees and the inferior quality of the trees left untouched in the cuttings, the matter does much to decrease the value of the forests. More regrettable is the fact that the forests in the worst condition are generally situated on the best trafficable sites and belong to the most productive foresttypes. As will be observed from Fig. 3, there are already districts in Finland, which in spite of the naturally favourable conditions and the great size of our forests, have been calculated to contain hardly sufficient forest for the needs of the local population. The more abundant stocks of forest are generally found in the forests of the State and the Joint Stock Companies. 


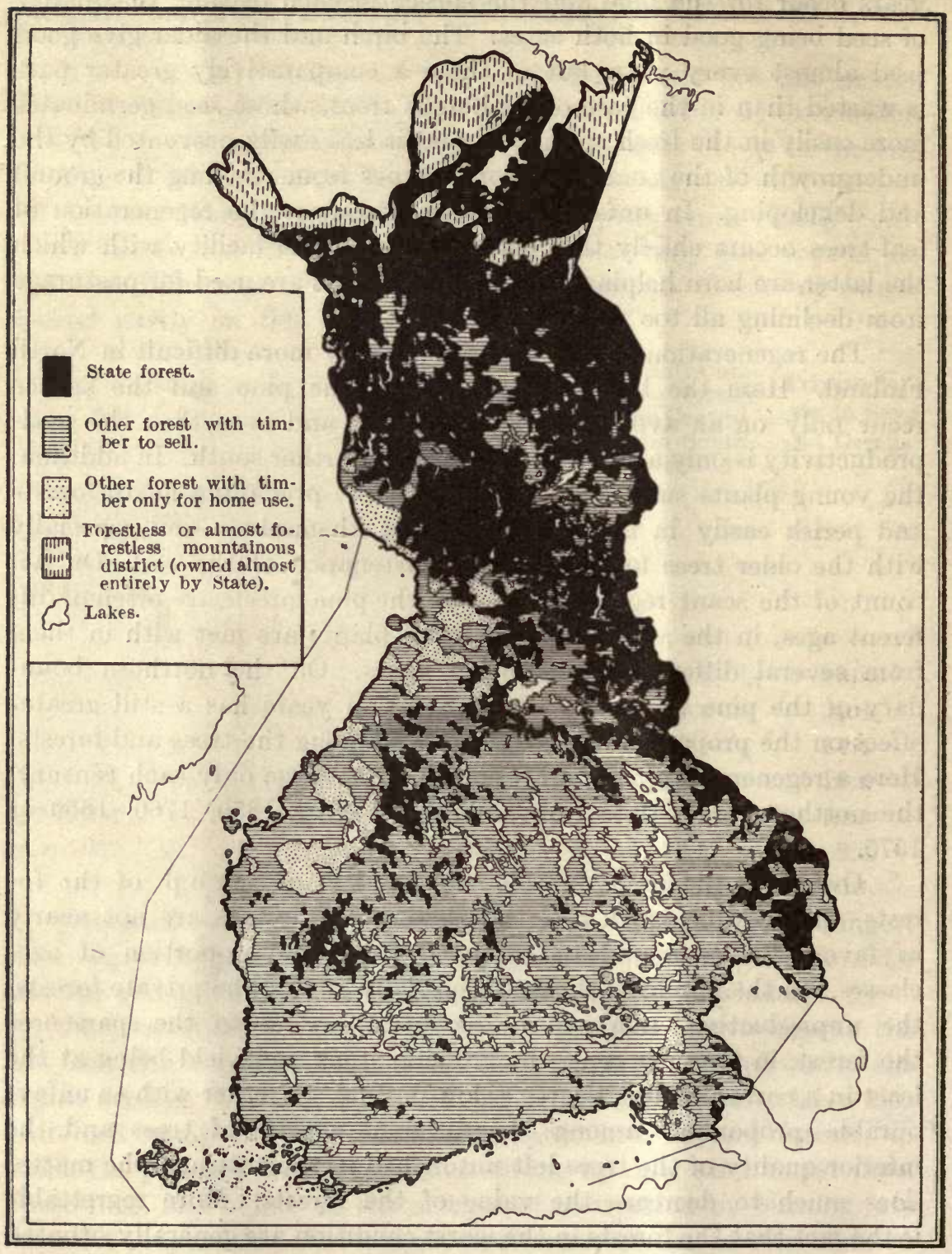

Fig. 3. Finlands forest resources.

Taken from: Bank of Finland, Monthly Bulletin. 

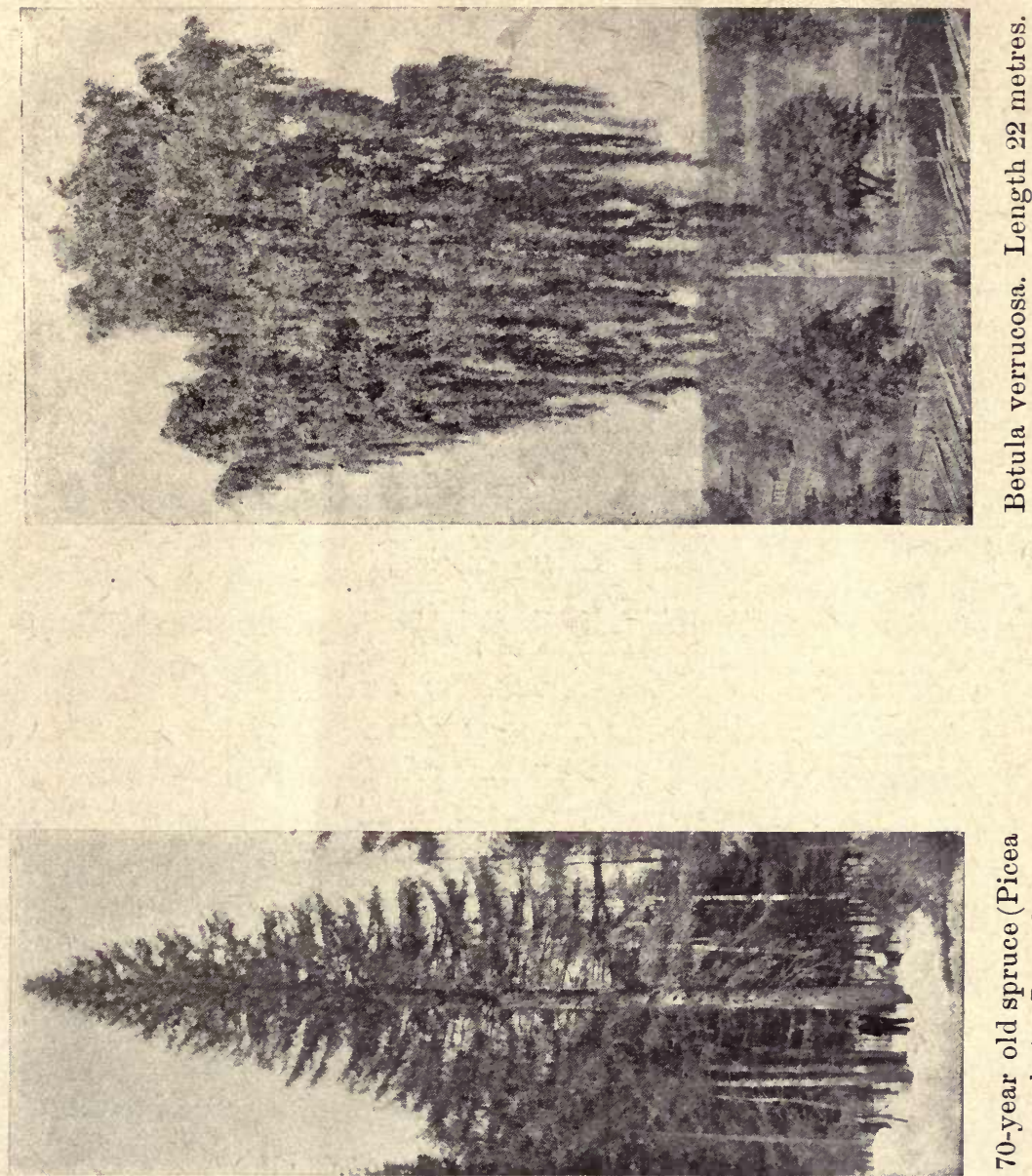

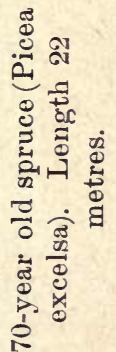
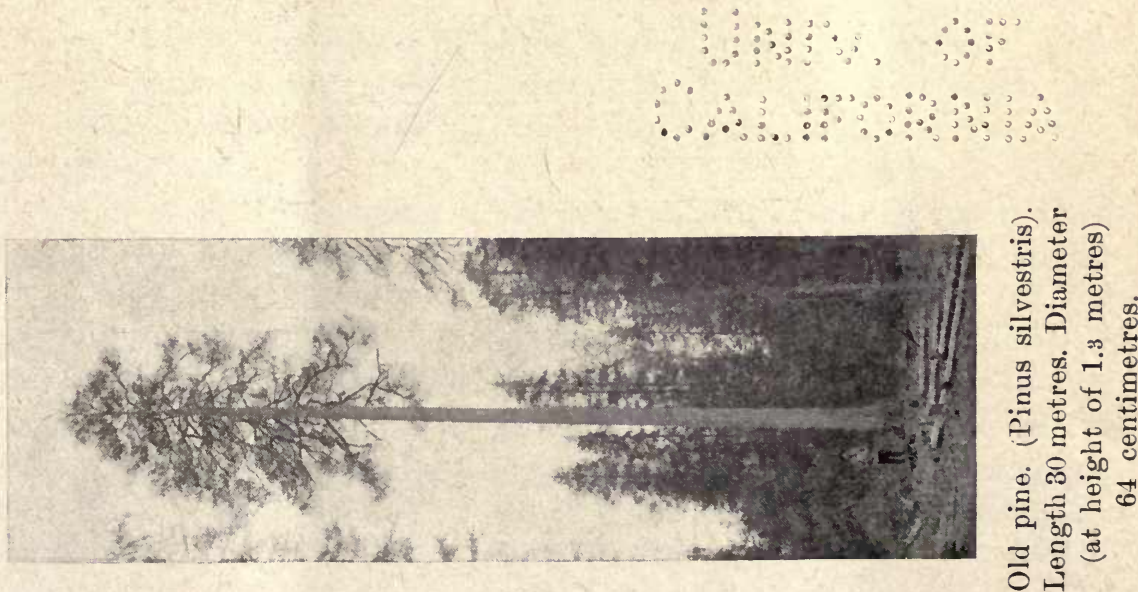

In the greater part of the country the market for timber is so good that cuttings in the forests can be carried out according to the rules of forestry, either as regeneration or improvement cuttings. Greater difficulties exist in this respect in the State forests of North Finland, where smaller timber from the birch or the pine cannot for the present be sold. The market for inferior timber is increased in all districts with even a scant population by the fact that a comparatively great part of the timber from the forests is ussed up by the farms themselves. Together with the cuttings of timber for sale, these cuttings for home consumption make even an intensive silviculture possible in a very great part of the country. The figures contained in the following calculation from the year 1916 show how great a part of the growing stocks of the country that are ripe for cutting is contained in these cuttings. According to this calculation the whole annual consumption of wood is divided among the various forms of consumption as follows:

1. Tops left in forests ...........

3399000 cub.metr.

$9.1 \%$

2. For home use of towns

1298000

3 . " " " rural population

15251000

(Consumption by traffic (without

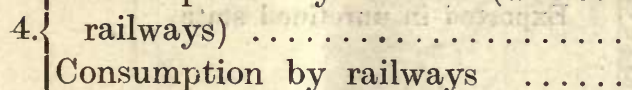

500000

809000

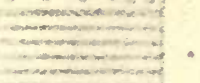

5. Fuelwood used by industrial work 3000000

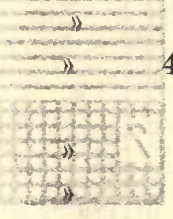

$3.5 \gg$

5. Raw material 9077000

40.9 "

7. Export in unrefined state .......

3965000

1.3 "

$2.2 》$

8.0 "

24.4 औ

10.6 "

Total 37299000 cub.metr. $100 \%$

A graphic conception of these figures, important already from the standpoint of national economy, is given in Fig. 4, in which, for the sake of greater simplicity, the consumption in traffic has been combined.

Almost as independent of the species and quality of the timber used for the greater part of the home consumption - of which about $70 \%$ is taken up by fuelwood - is the wood used for traffic and by the various industries as fuel. As raw material for industry and for the timber exported unrefined, only the best timber available in the forests can be used. Thus of the timber cut down annually, about $61.5 \%$ is inferior, including wood obtained in improvement cuttings and the remaining $38.5 \%$ of superior quality, for the greater part doubtlessly obtained from regeneration cuttings. 


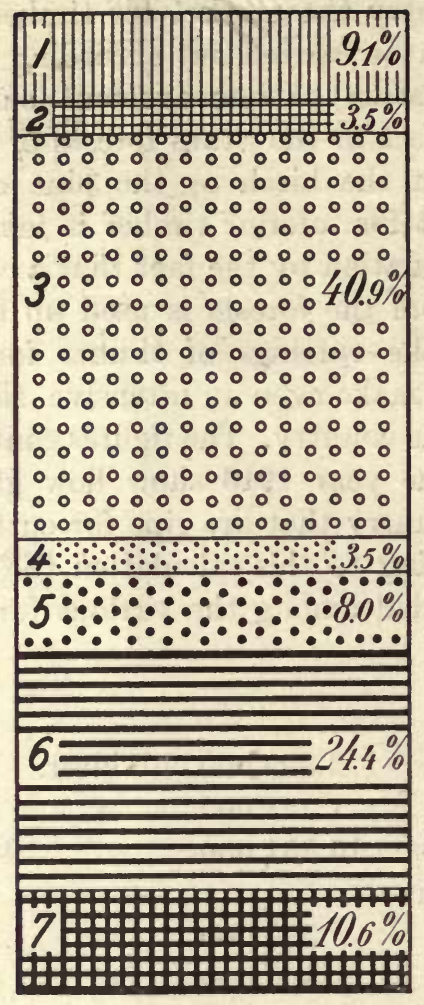

Tops left in forests.

Home use of towns.

Home use of rural population.

Consumption by traffic.

Fuelwood used by industrial works.

Raw material used by industrial works.

Exported in unrefined state.

Fig. 4.

Division of annual consumption of wood.

The future possibilities of forest management in Finland are shown with great clearness in a calculation touching the yield of the fertile forest lands of the Administrative Districts of Kuopio, Mikkeli (St. Michel) and Viipuri (Viborg). Assuming rational care of the forests, and that each forest-type contained the species of tree best. suited to it, and further, that the proportion of age-classes and growth, and in consequence also the growing stock, were fairly normal, the permanent annual yield would be somewhere about 21.9 million cubic metres, while in the present condition of the forests it is only slightly over one half of this amount, or about 11.6 million cubic metres.

\section{Forest Management Areas.}

The importance of forest management in the various parts of the country is decisively affected not only by the natural conditions of the locality, but also by their situation with regards to communications, before all, by their nearness to the waterways. In drawing up the following forest management areas, attention has been paid mainly 
to botanic geography and to the technical-economical factors on which business possibilities depend.

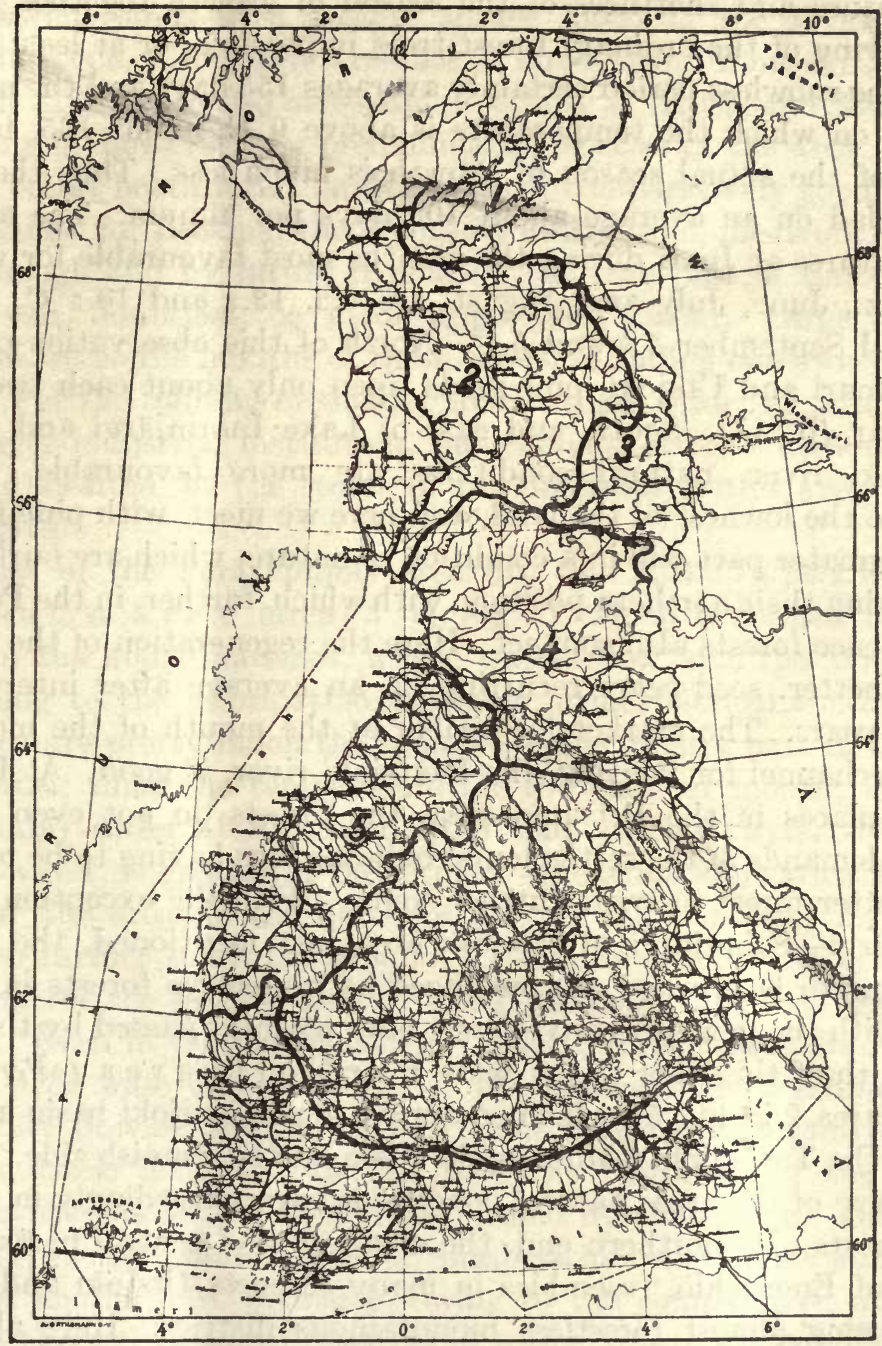

Fig. 5. Forest management areas.

1. Farther Lapland ( Perä-Lappi»).

2. Far North ("Perä-Pohjolas).

3. Knolajärvi and Kuusamo area.

4. Kainuu area.

5. Pohjanmaa (Österbotten) area.

6. Central Finland lake area.

7. Coastal area.

The most northern management area, F a r t h e r L a p land ("Perä-Lappi》), is formed by the basins of the Tenojoki, Paatsjoki and Iuttojoki rivers, all flowing into the Arctic Ocean, these basins comprising the Parishes of Utsjoki and Inari and the Petsamo (Petschenga) 
district, as will be seen from Fig. 5 (area 1). A great part of the area is forest-boundary and mountainous land (Fig. 1), in which the low temperature and shortness of the season of growth together render the thriving of the ordinary forest trees impossible, or at least uncertain. The snowless period certainly averages 155 days and the number of days on which the temperature is above $0^{\circ} \mathrm{C}$, about 165 , but the length of the actual season of growth is much less. Thus the birch is leaf-clad on an average about 108 days per annum. The average temperatures at Inari during the months most favourable for vegetation, viz., June, July and August, are 9.2, 12.8 and $10.5^{\circ} \mathrm{C}$, and in May and September 2.9 and 5.6. North of this observation-post, in North Inari and Utsjoki, pine-seeds ripen only about each twentieth cone-year (p. 11). South and east of Lake Inarinjärvi and on the Luttojoki river, natural conditions are more favourable, chiefly owing to the lowness of the land, and here we meet with pine forests, for the greater part still in a condition of nature, which are fairly good considering their northern position, with which, further, in the Petsamo area, spruce forests also connect. Here the regeneration of the forests is also better, seed-years recurring on an average after intervals of 10-15 years. The market for timber at the mouth of the most important channel for floating, the Paatsjoki river, is good. At Utsjoki and in places in the Petsamo area, the forests do not even suffice for the demands of the settlements, building logs having to be brought from better forest districts further south. With the exception of the Inarinjärvi-Salmijärvi-Luttojoki area just mentioned, the forests have now to be worked and managed as protective forests in accordance with the new protective forest laws recently passed by the Diet.

South of this area is the wide $\mathrm{F}$ a $\mathrm{r}-\mathrm{N}$ or th a r e a ("Perä-Pohjola») (area 2 in Fig 5), which comprises the Kemijoki basin and the part of the Torniojoki-Muoniojoki basin on the Finnish side. Owing to the size of the area, natural conditions vary exceedingly in its different parts. Its northern end, the northern and central parts of the Parish of Enontekiö, resembles in many respects Utsjoki and North Inari, being almost forestless mountainous district. Here also the snowless period averages 155 days, while in the central parts of the area it is $\mathbf{1 6 5}$ days and in the coastal district adjoining the Gulf of Bothnia 185 days. The period of leaf for the birch varies between 109-115 days. At Sodankylä, situated at the southern end of the northern half of the area the average temperature in May is $4.3^{\circ}$, that of June $10.7^{\circ}$, July $13.8^{\circ}$, August $10.9^{\circ}$ and September $5.3^{\circ} \mathrm{C}$. At Tornio, on the other hand, the corresponding figures are 4.2, 11.7, 15.1, 12.7 and $7.7^{\circ} \mathrm{C}$. In the circumstances abundant seed-years recur for the pines in the greater part of the area, on an average each tenth year, near the mouths of the rivers appreciably oftener. The last-named districts are also the best with regard to the quality of 
their forests, and become the better the closer the river-beds are approached. Most barren are the lands on the watersheds between the rivers, many of these lands being exceptionally wide, uninhabited "selkosmaita" lands with meagre spruce forest of the HylocomiumMyrtillus type. Unbroken stretches of birch, many thousands of hectares in extent, are also met with, especially at Kittilä and Sodankylä. The pine is, however, the predominating species of the area, forming on the better heath-forest lands forests of comparatively good growth. As channels for floating, the Kemijoki and Torniojoki rivers are suitable enough and by future regulation the transport of timber along them can doubtless be made appreciably easier. Large sawmills are situated at the mouths of these rivers, including one owned by the State. For the refining of smaller timber there is for the present only one larger industrial institution, but competitors can without doubt soon be awaited, as the stores of raw material in this area are still very great.

East of the Perä-Pohjola area lies the $\mathrm{Ku}$ o la järvi and $\mathrm{Ku}$ us a mo area (area 3 in Fig 5), which is formed by those parts of the above parishes, whose waters flow into the White Sea. According to the information available, atmospherical conditions in this area are pretty much the same as in the greater part of the foregoing area; thus, the temperature for the summer months does not appreciably differ at Kuusamo from that at Sodankylä. The rainfall, however, is greater in the former. The landscape varies considerably in the area; in the northern part of the Parish of Kuolajärvi and also further south the ground is mountainous, forests being here rare and for the greater part stunted, to be set apart as protective forests. Even in the flatter districts lonely, spruce-clad fells often appear. Over wide areas, chiefly of the Hylocomium-Myrtillus type, the spruce prevails unconditionally; pine is sometimes vainly sought after in these districts. In this way the boundary of the forests towards the naked fells is oftenest formed by the spruce. The better forest-types are found in greater numbers in valley lands and in the canyons on the fells, in which, owing to the comparative wealth of lime in the soil of the district, even grove-forests are common. The abundance of forestless $»$ letton-swamps and the comparatively small danger of frosts make the conditions for agriculture (especially cattlefarming) good, as soon as improved communications render the intensive practice of these possible. Until conditions become ordered and settled in Far-Carelia, forest management in this area will continue to be unproductive.

The $\mathrm{Ka}$ in u u a rea (area 4 in Fig. 5 ) is formed by the basins of the rivers Simojoki, Iijoki, Kiiminkijoki and Oulujoki. Here natural conditions are already appreciably better than in the fore- 
going areas. In the interior the snowless period averages 175 days, on the coast it is 10 days longer. In the greater part of the area, the birch is in leaf about as long as further north, only in the southern and western parts does the period last 125-128 days. The average temperatures for May, June, July, August and September at Kajaani (Kajana) are $6.2^{\circ}, 12.5^{\circ}, 15.3^{\circ}, 12.4^{\circ}$ and $7.2^{\circ} \mathrm{C}$ and at Oulu (Uleåborg) $6.0^{\circ}, 12.4^{\circ}, 15.7^{\circ}, 13.2^{\circ}$ and $7.9^{\circ} \mathrm{C}$. In a botanic geographical sense, this area forms the connecting link between the northern and the southern portions of the country; in the south of the area the forest-types of the latter are typical, in the north those of the former, and over large areas intermediate types prevail. The best lands are situated east of Lake Oulujärvi and on the Bothnian coast. Regeneration-years recur also considerably oftener in the south of the area than in the north. The north-east portion is the site of the most southern fells (mountains) in Finland, on the slopes of which the spruce is the prevailing species in most cases, similarly, also, in the Hylocomium-Myrtillus type forests of the heights and ridges further south, which are covered with moraine strata. The pine often forms comparatively large pine forests in the heath-forest types. On account of cuttings, barkings for resin-wood, etc., the forests particularly of the southern and western parts of the area are more variable and of less age than further north. Floating conditions are fairly good, inferior in the Iijoki river, however, until the necessary improvements in the floating channel have been made. The market for smaller timber is better than in the foregoing area, but the timber that might be reckoned in this class has for the present been exported in an unrefined state, or sent to the industrial works further south. Thus, as might be expected, only sawmills are met with at the mouths of the rivers, among them, however, certain of the largest in Northern Europe.

The Pohjanmaa (Österbotten) area (area 5 in Fig. 5) comprises the coastal belt between the Gulf of Bothnia and the long watershed called Suomenselkä. Many small rivers divide the area into different portions. The snowless period varies here between $215-225$ days and the birch is in leaf on an average 128 days. The temperature during the season of growth is shown by the mean temperatures at Vaasa (Vasa) for the months mentioned earlier, viz., $6.7^{\circ}, 12.5^{\circ}, 15.5^{\circ}, 13.6^{\circ}$ and $9.2^{\circ} \mathrm{C}$. Barrenest are the lands on the Suomenselkä watershed, the spreading of swamps being also greatest here; the district is actually the one richest in swamps in Finland. Further west, the land is generally flatter, inferior in the northern and central portions of the coastal district to that further south, where the most fertile lands lie around the town of Vaasa (Vasa). The forests are comparatively young pine or mixed pine forests. In places, however, the spruce predominates. The transport of timber 
is rendered easier by the railway running longitudinally through thearea, along which smaller sawmills are met with on the banks of the rivers. Owing to the smallness of the individual watercourses, larger sawmills are not to be found even on the coast, the smaller timber cut from the area for sale being sent in an unrefined state chiefly abroad. The Central Finländ lake area (area 6 in Fig. 5) comprises the huge basin bounded by the Suomenselkä, Salpausselk $\ddot{a}$ and Maanselkä watersheds, the waters of which flow through the Kokemäenjoki (Kumo) river into the Gulf of Bothnia, through the Kymi river into the Gulf of Finland and through the Vuoksi (Vuoksen) and the smaller rivers further north into Lake Ladoga. The wide lake-basin of Lake Saima with the connected waters is also in direct communication with the Gulf of Finland by means of the Saima Canal. The snowless period varies between 185-205 days and the birch is in leaf 125-140 days. Examples of the temperature are the following mean temperatures at Kuopio (months as before): $7.4^{\circ}, 13.6^{\circ}, 16.4^{\circ}, 13.5^{\circ}$ and $8.8^{\circ} \mathrm{C}$. The corresponding figures at Jyväskylä are $8.2^{\circ}, 13.7^{\circ}, 16.1^{\circ} 13.4^{\circ}$ and $8.3^{\circ}$ and at Tampere (Tammerfors) $9.0^{\circ}, 14.6^{\circ}, 17.0^{\circ}, 14.5^{\circ}$ and $9.7^{\circ}$. Regarding the average quality of land this area also divides in such a manner that the least fertile lands are those near the watersheds mentioned as confining the area. Particularly barren are the lands on the eastern border of the area (with the exception of the southern end), these lands forming a wide belt which comprises chiefly heath-forests. The reverse of the latter are the many wide grove-forest areas, vcentres of grove-forests", of which the most important are the Sortavala centre on the northern shore of Lake Ladoga, the Hollola centre around the southern ends of Lakes Vesijärvi and Päijänne, the Pirkkala centre beside the Kokemäenjoki river water-system and the Kuopio centre in North-Savo. The proportions of quality, the size of the area and the wealth of waters combine to make this area the most important of all the forest-management areas in Finland, which importance will increase the higher the productivity of the forests is raised by improvements in their condition. The fact is that particularly in this area, the forests need regulating in the matter of the species of tree composing them, and in their age-classes. Further, the unproductive portion of the forest lands needs afforesting. Good forests, are found in the area, however, in abundance, particularly on the lands owned by the Joint Stock Companies and on State land, especially in the eastern parts of the area. Within the area there are many comparatively large sawmills and other works for the refining of wood, but the greatest part of the timber cut in the area for sale or refinement is sent to the large industrial works at the mouths of the rivers mentioned and the Saima Canal. Smaller timber, including fuelwood, is sent also as such abroad. 


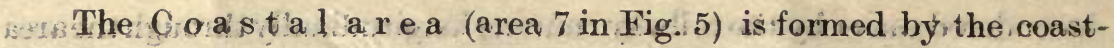
al belts of South-west and South Finland. In the matter of length of season of growth and temperature, this area is the most favourable in Finland. Thus the snowless period in the part furthest southwest is about 265 days and in the eastern part, where it is shortest, 205 days. The birch is in leaf on an average 140-150 days. At Turku ( $\AA b 0)$ the mean temperature in May, June, July, August and September is $9.1^{\circ}, 14.6^{\circ}, 17.1^{\circ}, 14.9^{\circ}$ and $10.2^{\circ} \mathrm{C}$, at Helsinki (Helsingfors) $8.8^{\circ}, 14.4^{\circ}, 17.0^{\circ}, 15.2^{\circ}$ and $10.4^{\circ} \mathrm{C}$ and at Viipuri (Viborg) $9.0^{\circ}, 14.6^{\circ}, 17.4^{\circ}, 15.0^{\circ}$ and $9.8^{\circ} \mathrm{C}$. Also in the matter of its. average quality this area is unconditionally the best. Ahvenanmaa (Aland) and the whole of the South-west Finland coastal district belong to a grove-forest area, similar to that which, slightly less fertile, is to be found between Viipuri (Viborg) and Käkisalmi (Kexholm). The propitiousness of the natural conditions of this area appears also in the fact that the nobler leaf-trees are here fairly commorr. The pine is to be regarded as the prevailing species, although the majority of the forests are mixed forests, for which, on account of the proximity of the coast and the otherwise favourable conditions, even an intensive culture is possible. Numerous larger and smaller timberrefining works exist in the area. The former, situated at the mouths of rivers flowing from the interior, use, however, the raw material produced in the lake area of Finland.

\section{The Proportion of Ownership of Land and Forest.}

The proportion in which land is owned and the species of land owned by the various land-owners have been decisively effected by the historical development of settling in the country, this depending again on its part on the appearance of arable land and on means of communication. The oldest settlements are met with chiefly on the banks of waters in South Finland in grove-forest centres of which we have spoken earlier. From these districts which were the most favourable to agriculture, settling has proceeded further along the lines of the most arable land and the easiest means of communication. In the north of Finland fixed settlements are even now restricted chiefly to the banks of rivers, which were earlier almost the only means of communication, the meadows on their banks providing further good opportunities for eattle-farming. When in 1542, Gustaf Vasa proclaimed the uninhabited wilds the property of "God, the King and the crown of Sweden", the State became thus possessed of the barrenest lands and those otherwise least suitable for cultivation. Still plainer is this the case with the lands which after the general re-parcelling ${ }^{1}$ ) of lands in the latter half of the eighteenth cen-

1) Before the "1so-jako", here translated as general re-parcelling «, land was held according to arbitrary divisions among settlers. The 1 1so-jako» was essentially a legal defining of boundaries. 


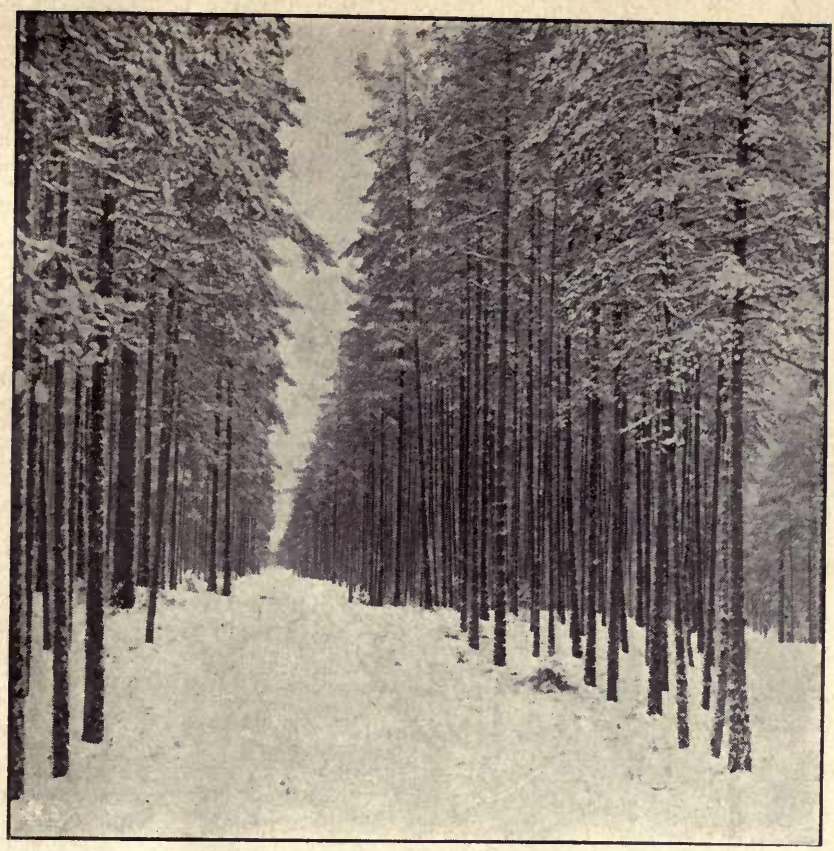

70-year stand of pines. (Pinus silvestris). Calluna type in South Finland.

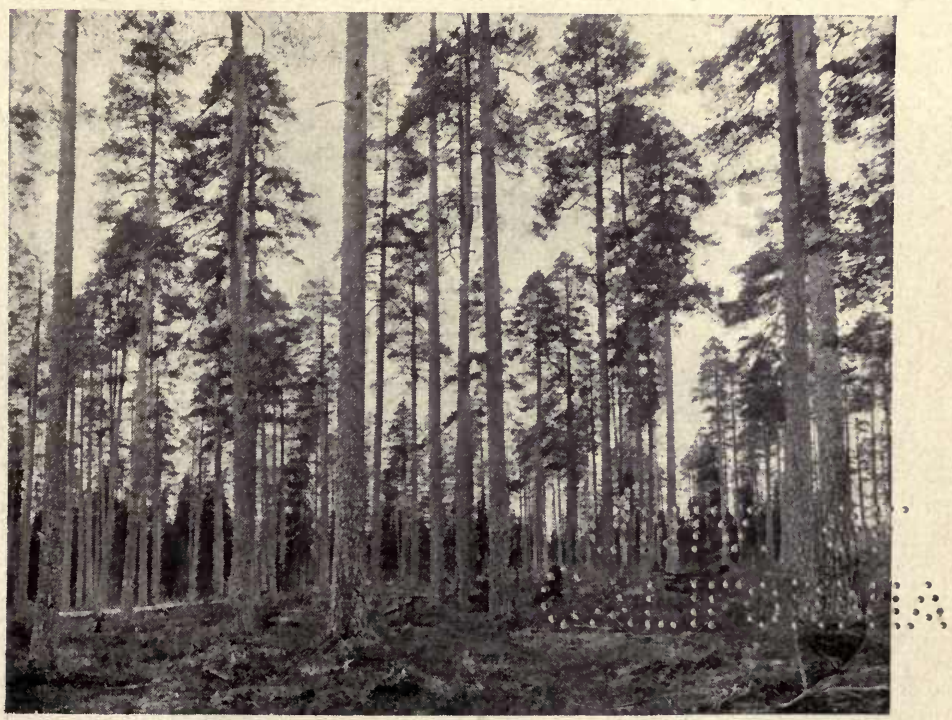

About 200-year old stand of pines (Pinus silvestris) in Central Finland. Vaccinium type. 


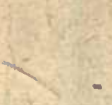

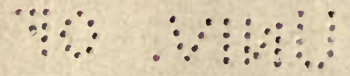

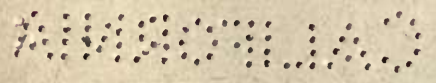


tury finally remained in the possession of the State as. "wilderness and superfluous land\%. And thus the ordinary State lands, as they will be called in the following in order to distinguish them from those state farms whieh earlier followed the holding of certain offices, here termed if $\mathrm{i}$ e f- $\mathrm{l}$ a $\mathrm{n} \mathrm{d}$ s», are in their overwhelming majority situated in the north of Finland - about $80 \%$ in the Administrative District of Oulu (Uleåborg) - and further south, chiefly in the barren areas around the watersheds. In part much more favourable is the situation of the areas added later to these lands, viz., the forests set apart for the State from the former "gift-lands" ${ }^{1}$ ) of the District of Viipuri (Viborg), the Annantehdas Factory forests at Suojärvi (made over to the State of Finland at the Peace of Tarto, 1920) and the land bought by the State, for the most part in South Finland, all these together forming an area of about half a million hectares.

Both in situation and in fertility of soil, the State fiefla $\mathrm{n} \mathrm{d} \mathrm{s} \mathrm{differ} \mathrm{from} \mathrm{the} \mathrm{ordinary} \mathrm{State} \mathrm{lands.} \mathrm{Although} \mathrm{these} \mathrm{were} \mathrm{earlier}$ given to Military and Civil officials for use either in lieu of or in addition to other salary, they have later been rented to private individuals. The State fief-lands are generally situated in the most arable districts near good communications. Their area only is very small compared with the State lands in general, forming $2.2 \%$ of all Stateowned lands under the control of the Board of Forestry.

Ecclesiastical fief-lands, scattered fairly evenly over the whole of the country, are generally among the best in their respective neighbourhoods.

Municipal forests are mostly situated beside water and are thus favourably placed with regard to means of communication. For the same reason they are extremely good regarding quality of soil, as near water the soil is usually fatter than at some distance away.

The latterly much-discussed question of land-ownership by the Joint Stock Companies is for the most part a fruit of the last few decades. The matter concerns chiefly the wood-refining Companies, which have bought mainly forest lands. As a result, the landed property of the Joint Stock Companies is for the most part situated in the comparatively unfertile watershed areas, forests being proportionally more common there than cultivated lands.

Regarding land owned by $\mathrm{p} x \mathrm{ivate}$ individuals, the course of settlement sketched in the foregoing has resulted in their being on the whole comparatively favourably situated with regard to the nature of their soil and their general situation. - Approximately the same applies to the recent purchases of land by the $\mathrm{r} u$ ral com muities.

2) These gift-lands are lands presented earlier by the Czar to Russian nobles, from whom the lands were purchased by the state of Finland, for division by sale among the tenant-farmers in possession. 
The facts dealt with in the foregoing appear again in the diagram.
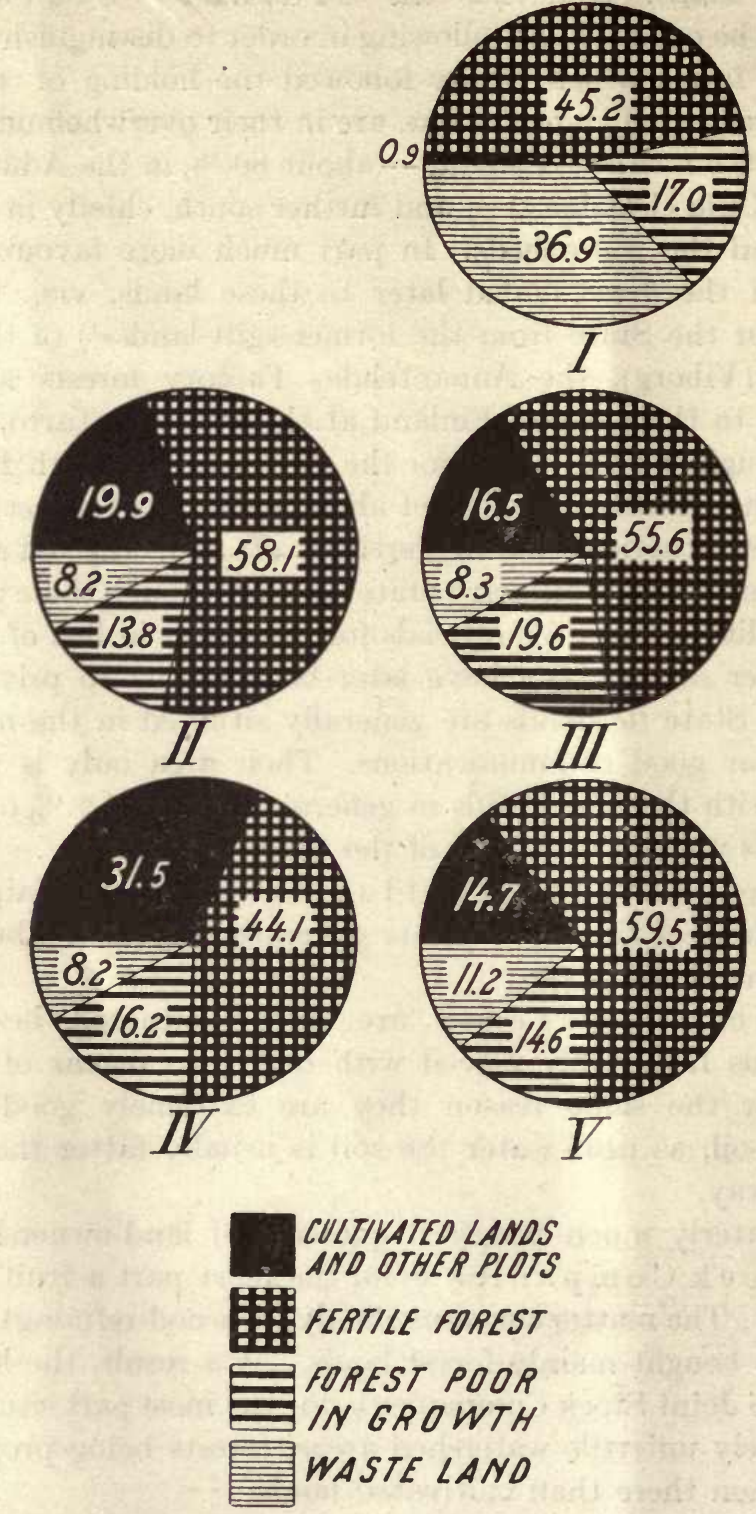

Fig. 6.

The proportion of the various kinds of land held by the different classes of proprietors.

\footnotetext{
I. State lands.

II. State fief-lands.

III. Ecclesiastical fief-lands.

IV. Municipal land.

V. Private land.
}

The greatest land-owner in Finland is the State. Slightly more than one-third of the whole area of the country is in its possession. 
In the following it will be shown separately how the total land-area of Finland and the total forest-area (lakes and rivers thus omitted) are divided among the various groups of owners. Petsamo (Petschenga) ${ }^{1}$ ) has here been left out of account.

\begin{tabular}{|c|c|c|}
\hline \multirow{3}{*}{ 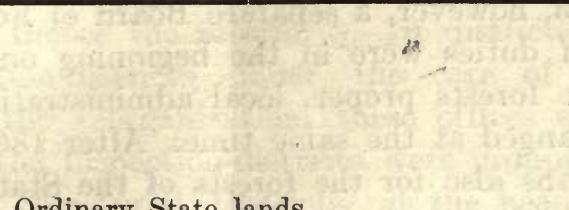 } & \multicolumn{2}{|c|}{$\begin{array}{c}\text { Proportion of ownership } \\
\text { in } \%\end{array}$} \\
\hline & $\begin{array}{l}\text { total land- } \\
\text { area }\end{array}$ & forest-area \\
\hline & 36.7 & 35.9 \\
\hline State fief-lands $\ldots$. & 0.9 & 1.0 \\
\hline Ecclesiastical fief-lands ............. & 1.0 & 1.2 \\
\hline Joint Stock Companies and associations & 7.2 & 8.1 \\
\hline Municipalites..................... & 0.3 & 0.3 \\
\hline $\begin{array}{l}\text { Rural communities ........................ } \\
\text { Other landed property (mainly private- }\end{array}$ & & 53.5 \\
\hline ownership) $\ldots . . . .$. & 53 & \\
\hline
\end{tabular}

The comparatively small area of lands in the possession of the State Railways and of certain lands bought by the State for various purposes is included in the item "Other landed property."

The ownership of forest lands is shown graphically in the following diagram, in which certain groups have been combined. See also Fig. 3.

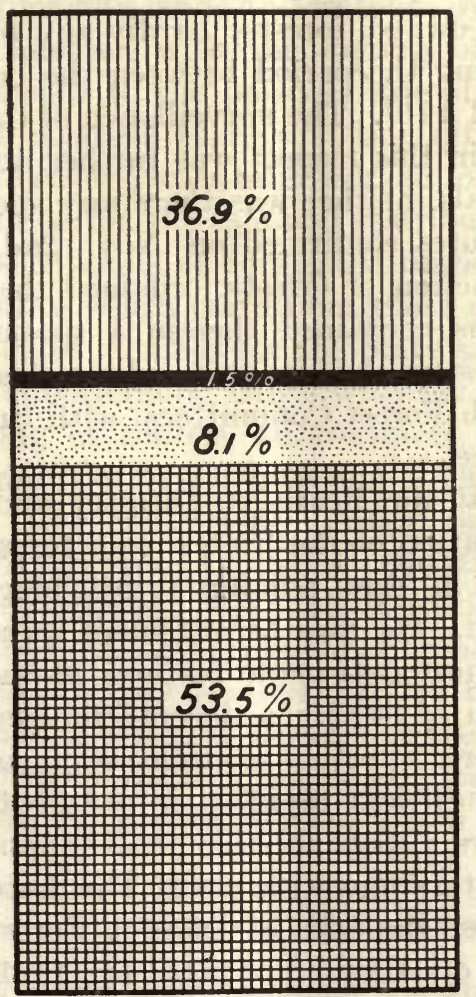

State.

Ecclesiastical fief-lands and municipalities.

Companies and associations.

Others.

Fig. 7.

The proportion of ownership of land.

1) The district on the Arctic coast, with an area of slightly over 1000000 hectares, acquired by Finland at the Peace of Tarto, 1920. 


\section{Forest Administration.}

For the administration of the forests a central organization was arranged in 1859, at first in connection with the Central Board of Surveying. Already in 1863, however, a separate Board of Forestry was established. Its chief duties were in the beginning only the economic care of the State forests proper, local administration for the said purpose being arranged at the same time. After 1863, the drawing-up of working plans also for the forests of the State fieflands was begun by the Board of Forestry, although these fief-lands remained otherwise under the control of the Governors of the respective Districts. When in 1915 a new regulation decreed that only arable and pasture lands were to be given out on rent, the forests of the fief-lands were transferred under the control of the Board of Forestry to be managed in the same manner as the other State forests. Since the year 1893 it has also been the task of the Board of Forestry to draw up working plans for the forests of the ecclesiastical fief-lands, the revenue from these plans to be made over, however, to the manses and the. lands following the post of choir-leader, and to the socalled "building-funds" of the respective parishes.

Regarding the care of privately-owned forests, hardly any restrictions whatever were in force during the period between the beginning of the nineteenth century and 1917. The surveillance of the few stipulations ordained by the law in this respect was further not in the hands of Forestry Board officials, neither was there any special organ for the purpose. The statutes confirmed on Nov. 2nd., 1917, for the prevention of the destruction of forests, ordained that for the surveillance of the regulations contained therein a special District Forest Committee was to be established in every administrative district and to assist these, Parish Forest Committees, with the Board of Forestry as a higher instance.

The accumulation of new tasks at the Board of Forestry and, before all, the widening and multiplication of the States' own forest economy, compelled certain alterations in forest administration, more particularly in the central organization. The new arrangement came into force on July 1st., 1921. The most noticeable features of the reform were: a more complete division of labour, a decentralization of less important matters with a more effective concentration of vital matters, a sharper control and sufficient rapidity, in the treatment especially of business matters. Also in the local administration of the State forests great alterations were made. The State forests are divided into districts under the care of District Forest Superintendents there being 102 of these districts in 1921, including the fief-land forests and the experimental areas of 
the schools of forestry. For the better organization of the superintendence of labour and their surveillance, the districts are divided into watch-areas, each of which possesses its own watchman. The number of watch-areas in the State forests proper was 801 in the year 1921. Before the reform, $9-10$ districts were grouped together in inspection-districts under the care of an Inspector of Forests With the reorganization, these offices were abolished and in their stead the inspection-districts were-grouped in twos and threes into larger Directorial Districts, at the head of each of which there is now a District Office.

The Board of Forestry itself is now divided into two sections: State Forest Section and Private Forest Section, with mutual cashier's, secretarial and statistical offices. The State Forest Section comprises four departments: management, land, engineering and business departments. The Management Department directs the mapping of State land and draws up valuations and working plans. The Land Department, besides directing matters connected with the use of land, effects the purchase of new land for the State. The Engineering Department attends to the improvement of transport conditions and the drying-up of marshy lands and watches over the interests of forestry in matters connected with the rafting of timber. The Business Department attends to the business side of Forestry. For the different branches of business there are four offices: - 1) Timber-sales Office, which effects the sales of unworked forest products, 2) a Timber Distributing Office for the sale and distribution to consumers of firewood and all other kinds of completed timber except sawn timber, 3) a Contracting Office which carries out State cuttings in all districts, with the exception of cuttings for the State sawmills and firewood factories, and 4) a Timberrefining Office with the control of the State works for the refiuing of timber, all contracts on behalf of these, and the sale and transport of the products of the said works.

In the Private Forest Section there are two departments: a Private Forest Control Department, whose duties include the superintendance of forestry education, and a Managing Department for fief-lands and communal forest. The latter department draws up the working plans demanded by the law for such forests as are not managed for the account of the State, and supervises the carrying-out of these plans. The common forests of new settlements come under the care of the Colonization Board in this respect.

\section{State Forest Management.}

The way in which the areas of the State forests and the State fief-lands are divided into the various classes of land appears from the following. 


\begin{tabular}{|c|c|c|c|c|}
\hline (3) & $\begin{array}{l}\text { State } \\
\text { land }\end{array}$ & & $\begin{array}{l}\text { State fi } \\
\text { lands }\end{array}$ & ef- \\
\hline ted & 102647 & Hect. & 56759 & Hect. \\
\hline forest & 5529995 & 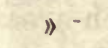 & 165855 & " \\
\hline Forest-land poor in & 2083733 & 1) & 39225 & " \\
\hline Waste land & 4514792 & " & 23392 & \\
\hline Tater & 455658 & 》 & 5622 & \\
\hline
\end{tabular}

Total 12686825 Hect. 290853 Hect.

In addition to these, there is yet the Petsamo area, comprising slightly over a million hectares, of which the portion growing coniferous forest has been estimated at about 330000 hectares.

The area of the fief-lands will be greatly diminished when the small farmers and cottagers now renting patches of them take advantage of the new law of 1922 , according to which they can redeem the land held by them for their own. Another law touching the colonization of the State land, approved also in 1922, will further help to decrease these lands considerably. The effect on the results of State forest management will be all the more detrimental, as the land thus ceded will be for the most part that most profitable to hold.

The growing stock of timber in the ordinary State forests (not including Petsamo) is 342 million cub. metres, of which $27 \%$ is formed by coniferous large timber-trees (fir or spruce trees with a minimum diameter of 25 centimetres at a height of 1.3 metres). The total number of these latter is 211 million trees. - The total growing stock in the forests of the State fief-lands is 19 million cubic metres. Of this, $34 \%$ is made up of fir or spruce timber-trees, the number of which is 14 million. - The timber of the Petsamo area has been estimated at 15 million cubic metres.

As has been mentioned earlier, the State lands are divided extremely irregularly among the various districts of the country and are for the most part unfavourably situated. The latter factor naturally affects the possibilities of sales and prices, with unfavourable results for the economic situation as a whole.

The cuttings in the ordinary State forests has lately varied between $0.28-0.53$ cubic metres per year and hectare of fertile forest. The corresponding figure for State fief-land forests in 1919 wäs 2.7 cubic metres. The degree of cutting affixed in the plans of management is on an average, including the fief-lands, about 0.7 cubic metres, considerably more thus than the cuttings in the ordinary State forests. The amounts cut down might in these circumstances be greatly increased with a view to the condition and growth of the forests, but the possibilities of sale render this difficult. In the State public 
timber auctions a great part of the lots of timber offered for sale has either met with no bidding at all, or the bids have been so low that it has been impossible to accept them. This is shown by the following figures:

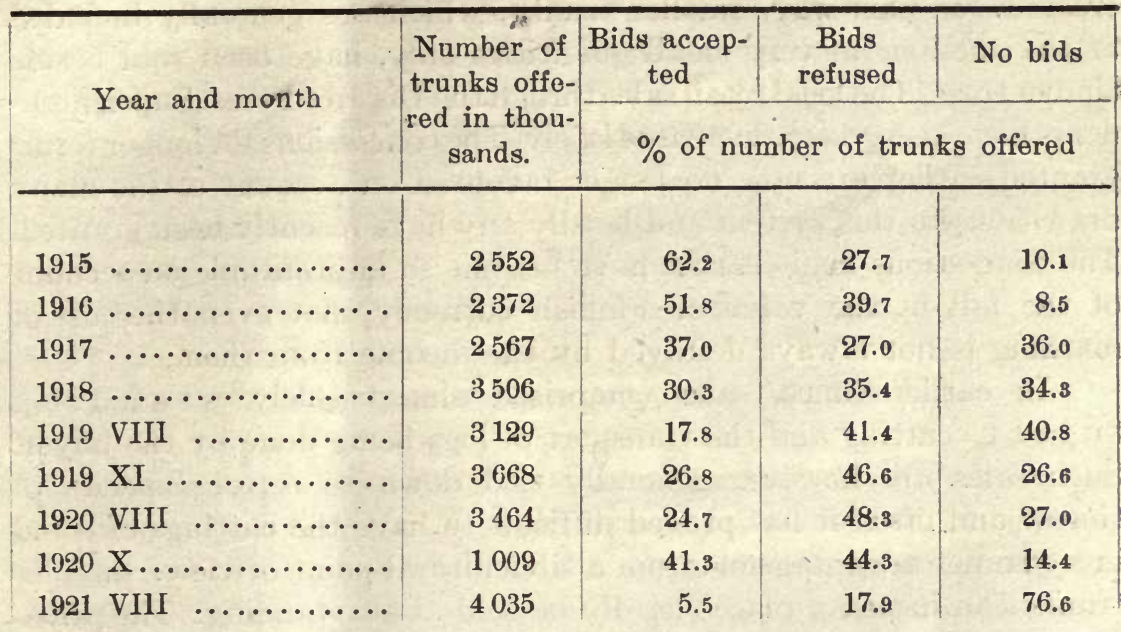

A great part of the unsold trees was certainly sold after the auctions by private agreement, but in any case and especially in North Finland, the demand for even large timber-trees has been smaller than the quantities available. Smaller trunks have met with an extremely slight demand in North Finland, and it is just there that the majority of the State forests are situated. This renders an increase in the amount of cutting still more difficult in the present circumstances, as the additional cutting would thus have to be directed to trees of greater calibre only, in the case of which additions of any magnitude cannot be made.

The whole of the cuttings carried out during the latter years will be seen from the following:

\begin{tabular}{|c|c|c|}
\hline Year & $\begin{array}{l}\text { Total cuttings } \\
\text { in thousands } \\
\text { cub. metres }\end{array}$ & $\begin{array}{c}\text { Of which large } \\
\text { timber } \\
\%\end{array}$ \\
\hline 1917 & .. $\quad 2850$ & 34.6 \\
\hline 1918 & .. $\quad 1509$ & 28.6 \\
\hline 1919 & $\ldots \quad 2376$ & 53.2 \\
\hline 1920 & $\ldots \quad 1970$ & 49.3 \\
\hline
\end{tabular}

In 1920 the percentage of large timber in the cuttings in the Lapland inspection district reached $86.9 \%$ and in the Kemi inspection district $72.5 \%$.

The chief method of selling has been the $\mathrm{p} \mathrm{u} \mathrm{b} \mathrm{lic} \mathrm{a} \mathrm{u} \mathrm{c} \mathrm{tion.}$ So-called general auctions have generally been held each year at 
Oulu (Uleảborg), Tampere (Tammerfors) and Viipuri :(Viborg), and so-called local auctions in different parts of the coantry. "The significance of this method has lately dwindled, especially in the case of the local auctions. Instead, sales by agreement have greatly increased. In this way, smaller trunks, which are generally included at the auctions in very small quantities only, have been sold beside timber trees. The local retail sales throgh the District ForestSuperintendents have also greatly increased lately. The concessions for longer terms granted earlier are now no longer favoured on account of the many drawbacks to this system and hardly any have recently been granted. The concessions made earlier have become so unprofitable on account of the fall in the value of Finnish currency that even the cost of marking is not always defrayed by the income from them.

In earlier times, sales comprised almost solely s t a n d ing f o rest, cutting and the transport of logs being done by the buyer. Such sales are however generally tied down to certain species of timber and often it has proved difficult to have the cuttings effected in a manner advantageous from a silvicultural point of view. Smaller trunks can in many places hardly be sold at all, standing. The prices at such sales are further greatly dependent on the buyer and are generally much too low. These and many other reasons speak for the cutting and the preparation of the timber by the State itself. At the beginning of the century the Board of Forestry actually commenced to take part in cutting contracts. Originally, the purpose was only the satisfaction of the State Railways' demand for firewood, but later, during the war, these contracts were greatly widened. Firewood was delivered to other Government institutions, to the large centres of consumption and to private individuals even. And further, the preparation of other timber products also, pit-props, railway-sleepers, small square timber, logs, etc., was undertaken. Of prepared cordwood (firewood) the Forestry Board has delivered the following amounts:

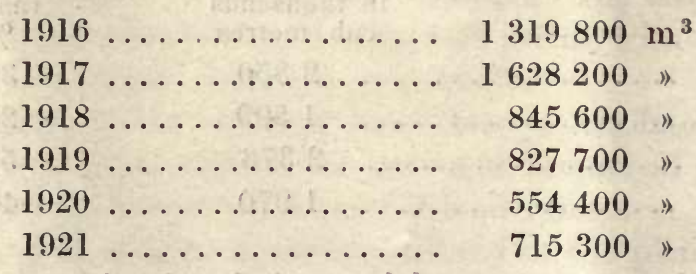

At the time when the cutting of firewood for the State railways was commenced through the instrumentality of the Board of Forestry, plans were set afoot for the satisfying of the railway's demand for sawn timber from the States own sawmills. The possibility thus awoke 


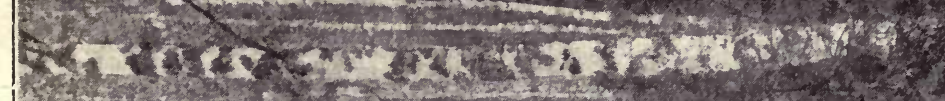

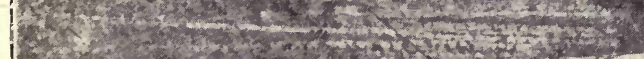

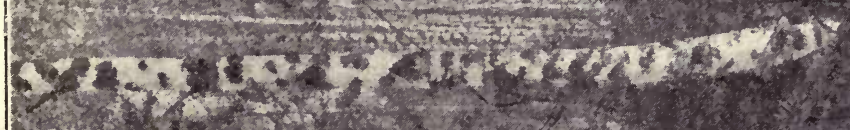

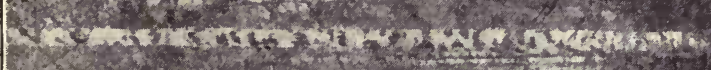

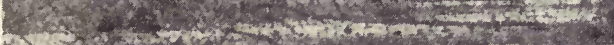

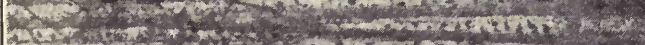

L

2.

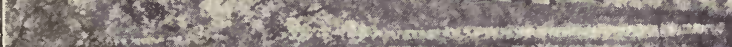

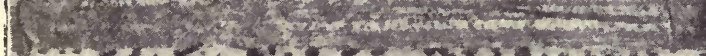

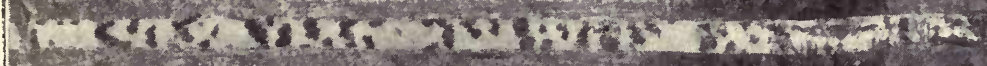

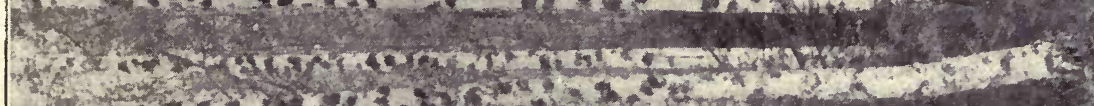

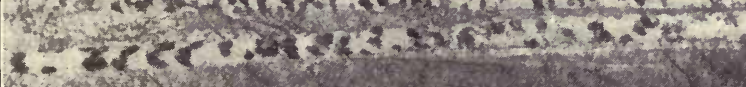

-

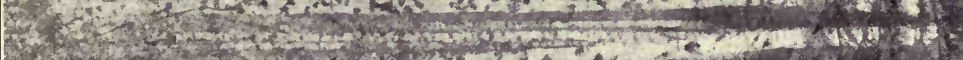

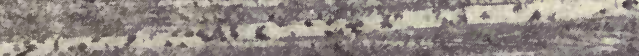

S.

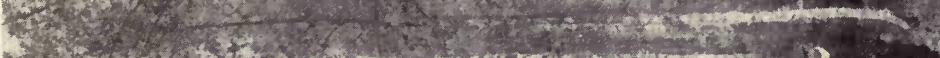

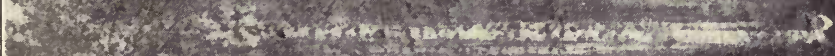

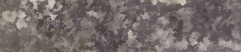

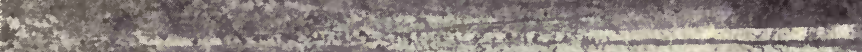

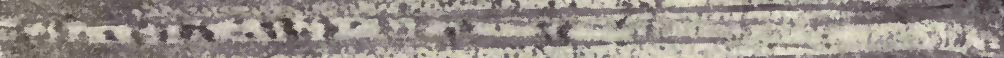

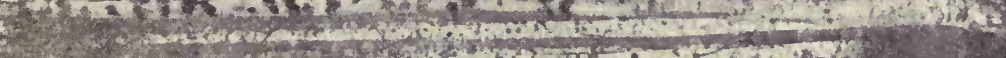

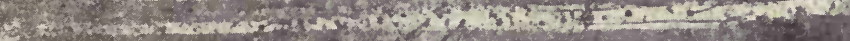

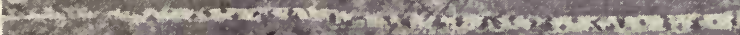

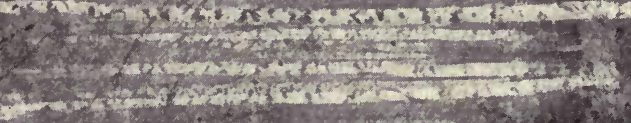

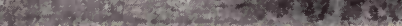

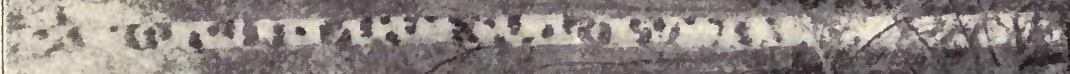

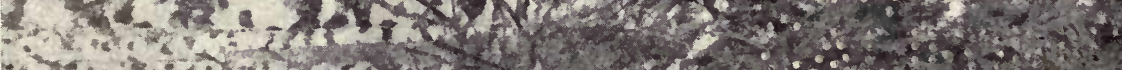

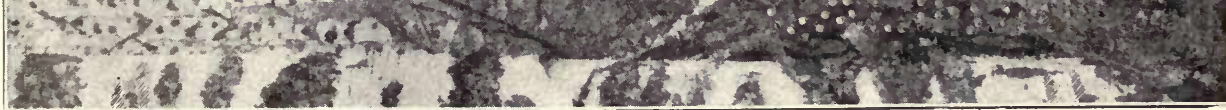


$\because \square^{\circ} \quad \vdots \vdots \vdots \vdots \vdots \vdots \vdots$

sond 
of using up second-rate timber-trees and other trees doomed to elimination for silvicultural reasons, which material otherwise was difficult to dispose of . In the year 1905 followed the building of the first State sawmill at Siuro, another was built in 1908 at Lieksa (Kevätniemi Sawmill) and a third in 1909 at Sukeva. The sawmill at Lieksa is three-framed, the others two-framed. Still under building are the Veitsiluoto Sawmill at the mouth of the Kemijoki river, which is intended for completion this year as six-framed, though the plans allow of an extension up to twelve frames. Its founding was brought about mainly by the poor possibilities of sales from the great State forests in North Finland. Besides these sawmills in the true sense of the word, the State owns two larger firewood sawmills: those at Uuksu and Uimaharju. - The greater part of the products of the Siuro, Kevätniemi and Sukeva sawmills is nowadays sold abroad, although, as mentioned earlier, they were originally founded chiefly for the sake of the State railways. In the year 1921, for example, sawn timber for close on 17 million marks was sold abroad. The significance of state enterprise in this matter lies, not only in the improvement of sales from the State forest, but also in the fact that the Board of Forestry is thus enabled to follow the variations in timber prices abroad, and in transport and refining expenses at home, and by means of its contracting activities, to find a trustworthy base for its pricing of growing forest. Further, through the sale of sawn timber, the State receives a supply of foreign currency. - The situation of the three sawmills in the interior is naturally unfavourable from the point of view of export. The new sawmill at Veitsiluoto will, on the other hand, be in direct communication with countries abroad. - The combined annual profits of the State sawmills has been:

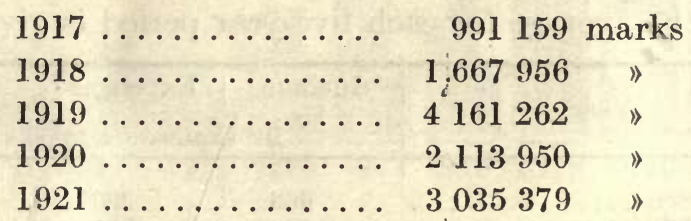

The diversification of the business side of the State's forest management pictured in the foregoing will make it easier to take advantage of the business conditions prevailing at different times and thus help to improve the economical results.

An important factor in the improvement of prices and market conditions is the facilitating of transport possibilities. In this respect the most important matter is the improvement of floating and rafting conditions. Especially in the case of the larger rivers in North Finland, which are of exceedingly great importance for the State forests, has rafting been greatly hindered by the defective cleaning of the rivers, by controversies over fishing 
interests and the slowness with which the rafting regulations have been completed. Within the State lands, rafting conditions are improved each year by the cleaning-up of rivers and brooks, by the building of dams, wet slides, etc. - Between Ylikitka and Livojärvi the State possesses a contrivance which makes it possible to transport logs from the North Kuusamo waterways to the Iijoki waters. As logs are generally transported during the winter in Finland, the existence of a network of roads is not of as great importance here as it is in many places abroad. But even roads are improved and developed each year in the State forest districts. - At present, the building of a light railway from the stopping-place of Eskola on the Oulu railway into the interior is in progress on behalf of the State.

An attempt is being made to improve the productivity of State land, not only by purely silvicultural activities, but also by draining bogs and swamps and thus increasing the area of forest land. Together, the bogs and marshes on State land form an enormous area: about 5.6 million hectares. Of this, bogs suitable for draining form only $35 \%$, or 2 million hectares. Organized draining has been attempted in the State forests only during the last decade or so. During this period about $13 \%$ of the drainable bog areas has been examined by eye for draining and 31000 hectares finally drained, or $1.6 \%$ of the total drainable area. - Besides increasing the area of forest land, the draining of swamps is important as a preventive to further spreading of the swamps. In the Province of Pohjanmaa (Österbotten), for example, about $95 \%$ of the present swamp areas has been born by the bogging of dry forest land.

The income, expenditure and profit accounts of the administration of the forests will be seen from the following. For the years $1861-1915$ the average for each five-year period is given.

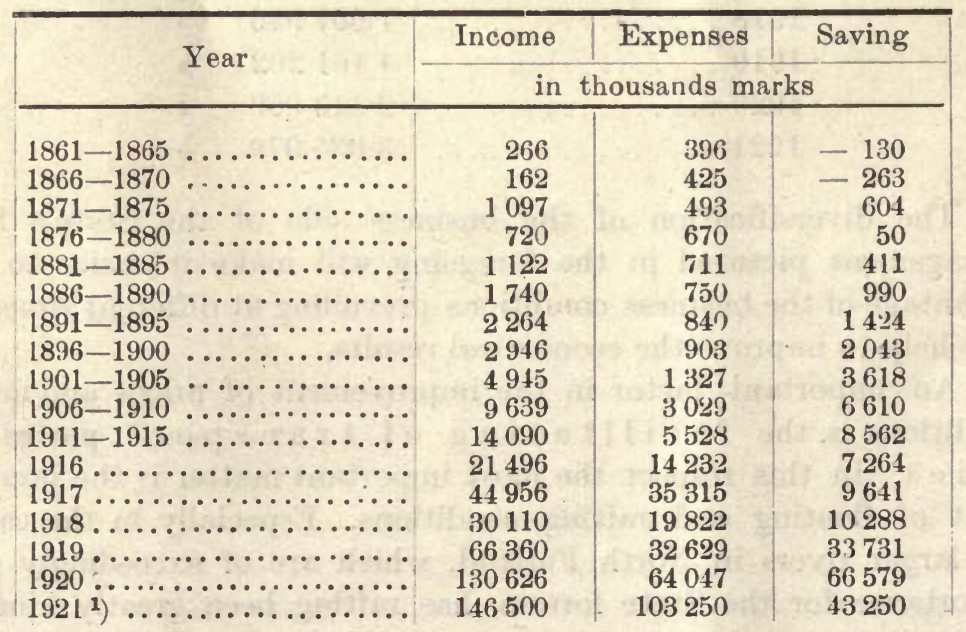

1) 'The figures for 1921 are based on preliminary reports. 
In connection with these figures it is to be noted that they do not as such give the results of the State's own forest management, the expenses including such items as the cost of forestry education, the expenses for the silvicultural Experimental Station, the surveillance of the forests of the ecclesiastical fief-lands and of private individuals, the purchase of land and other real estate, which can hardly be regarded as ordinary expenses. The income from the various inspection districts for 1920 shows a profit per hectare of forest land and arable land averaging 14: 23 marks for the whole country, this varying in the different districts between 98: 30 marks (Inspection District of Turku and Häme (Åbo and Tavastehus) and 2: 44. marks (Inspection District of Lapland).

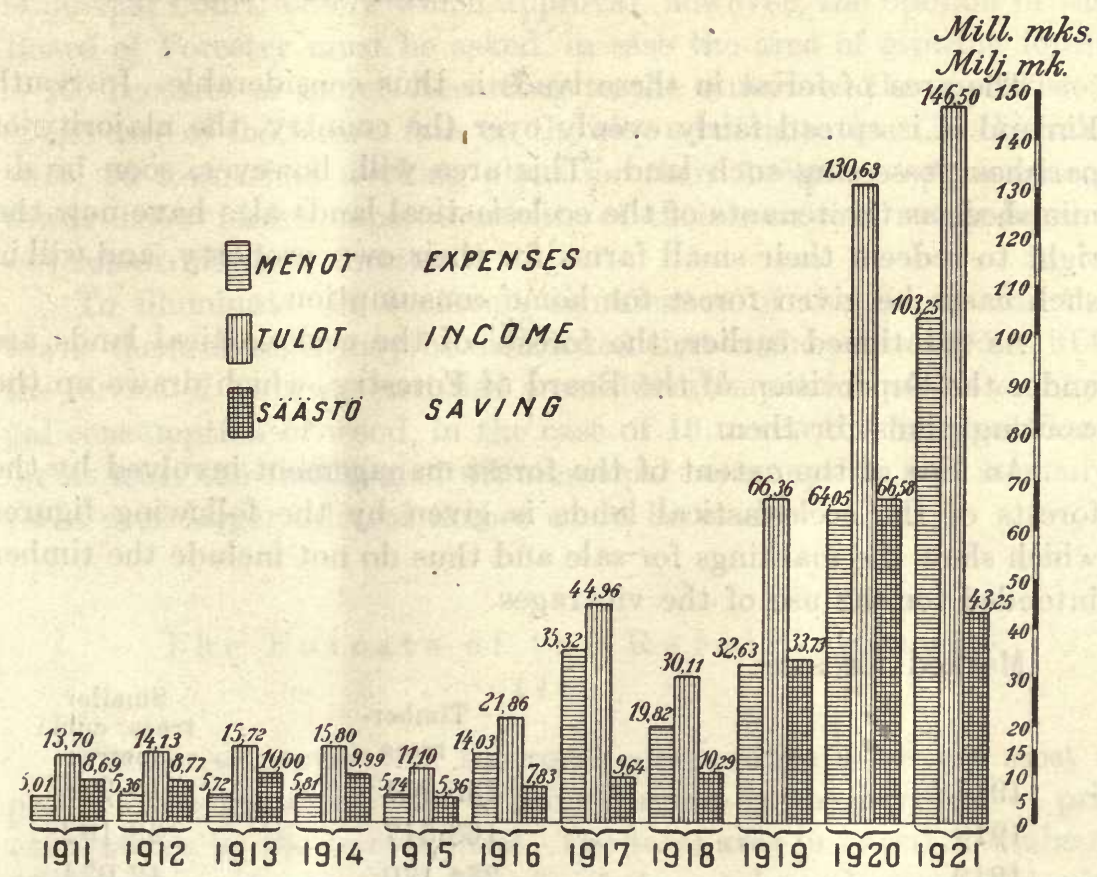

Fig. 8.

Financial results obtained by Board of Forestry.

\section{Communal and Private Forests and Their Management.}

The Ecclesiastical Fief-lands.

The ecclesiastical fief-lands are in a way endowments, the proceeds of which are to be used by the parishes for ecclesiastical purposes. The products of their forests satisfy in the first place the demands of the vicarages and of the estates of other Church officials. 
In the measure in which the forests can bear greater cuttings, the superfluous timber is sold, the proceeds of these sales falling to the so-called "building-funds», as has already earlier been stated.

The division of the area of these lands will be seen from the following:

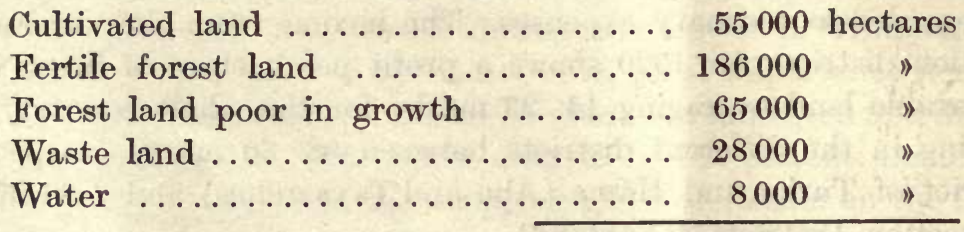

Total 342000 hectares

The area of forest in these lands is thus considerable. In South Finland it is spread fairly evenly over the country, the majority of parishes possessing such land. This area will, however, soon be diminished, as the tenants of the ecclesiastical lands also have now the right to redeem their small farms for their own property, and will in such cases be given forest for home consumption.

As mentioned earlier, the forests of the ecclesiastical lands are under the Supervision of the Board of Forestry, which draws up the working plans for them.

An idea of the extent of the forest management involved by the forests of the ecclesiastical lands is given by the following figures which show the markings for sale and thus do not include the timber intended for the use of the vicarages.

Marked for sale:

\begin{tabular}{|c|c|c|}
\hline & $\begin{array}{c}\text { Timber- } \\
\text { trees }\end{array}$ & $\begin{array}{l}\text { Smaller } \\
\text { trees, cubic } \\
\text { metres }\end{array}$ \\
\hline 1917 & 235944 & 15928 \\
\hline 1918 & 163517 & 28102 \\
\hline 1919 & 274170 & 42074 \\
\hline 1920 & 261256 & 18338 \\
\hline
\end{tabular}

The Municipal Forest.

The area of forests owned by the municipalities was $60000 \mathrm{hec}-$ tares in 1915, of which the part used in an economical sense was, however, only $65 \%$. The rest was made up of parks, etc. - Mostly, the real estate owned by the towns has been a gift from the State. Lately, land has also been purchased by them.

The towns owning the most forest and the areas of these will be seen from the following: 


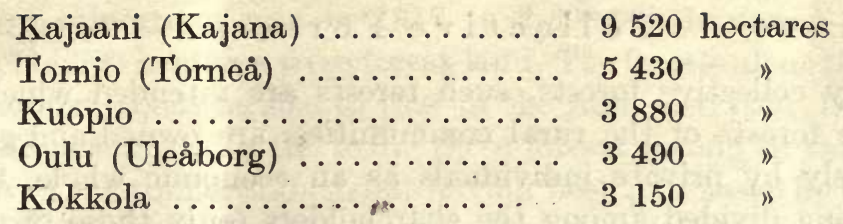

Four towns own areas of $2000-3000$ hectares of forest, nine own $1000-2000$ hectares. The areas owned by the remainder are under 1000 hectares.

The Forest Law of 1886 demands working plans for the municipal forests, which shall be approved by the Town Councils or the Municipal Court, before which approval, however, the opinion of the Board of Forestry must be asked, in case the area of growing forest is $\mathbf{1 0 0}$ hectares or more. According to the same law, the supervision of the care of the forests falls on the city administration. In the year 1915, 26 towns had working plans for their forests. - A couple of towns have forest superintendents of their own and many have a watchman for their forests.

To illuminate the economic significance of the forests for the towns themselves, it may be mentioned that in the years 1905-1914, the forests of 14 towns satisfied a considerable portion of the municipal consumption of wood, in the case of 16 towns the forest sufficed for at least the fulfilling of all municipal consumption and in many cases even larger sales of timber could be made.

The Forests of the Rural Communities.

The forest property of the rural communities is for the most a product of quite recent times, being formed by the purchase of private estates by the communities. The total area in question is about 170000 hectares. In $1917,63.5 \%$ of the total rural communities in the country owned landed property. - Forest economy has as a rule not yet reached any higher standard in the case of these lands. Actually, the rural communities have not purchased their land for use as communal forests, with a view to organized forest management, at least, not in the beginning, but for the greater part for quite other reasons: for use as poor-houses, elementary schools, hospitals, etc. Now, at the present time, forestry has progressed so far that in many rural communities a considerable portion of the communal budget is covered by income from forests. - The care of the forests of rural communities proper is not affected by any regulations in the laws now in force, a matter that urgently needs revision. 


\section{Collective Forests.}

By collective forests, such forests are intended which, apart from the forests of the rural communities, are owned and governed collectively by private individuals as an economic whole, the proceeds being divided among the shareholders (only those owning the land thus) according to principles drawn up amongst themselves. The Forest Law of 1886 assumes that such forests can be formed by a voluntary a greement among the landowners combining their forests under a single administration. It is not known that any of the collective forests should have been formed in this way. On the other hand, some have been brought about in the g r e a t re p a $\dot{r}$ c e 1 ling of lands. The largest of these collective forests will in the future be in North Finland in certain parishes in which the great reparcelling is still unconcluded. - More numerous are the collective forests that have resulted from the colonization activities of the State and the rural communities. These are generally, however, fairly small. Altogether there are now 67 of the latter, their total area being 20350 hectares. These forests are controlled by the Colonization Board. Working plans are drawn up for them by the Board in question, which also supervises their application. Certain of the collective forests in this group have been divided among the shareholders, at the request of the latter, and attached to their individual parcels of land. - Two collective forests, with a total area of 5362 hectares, were formed on the former "gift-lands» of the Administrative District of Viipuri in such a manner, that the State made over a couple of State parks, formed from the "gift-lands" at the time of their redemption, to the former tenants of the lease-farms, following in this an old promise given by the Senate. Applications for the ceding of other State parks formed in like manner for collective forests have been made to several Diets. The matter has not as yet, however, been finally decided. The two forests in question are worked on working plans approved by the Governor of the district.

In order to thrive, the exploitation of a collective forest demands a strong sense of solidarity and mutual trust among the partners in the same. Envy and quarrels are, sad to say very common occurrences among the partners in our collective forests, for which reason the idea of collective forests has not led to such good results in practice as the promoters of the idea awaited.

Forests of the Joint Stock Companies.

A considerable group among the landed proprietors of the country is formed by the Joint Stock Companies. Including quite small properties owned by various associations and societies, the area of land 
owned by this group rose in 1917 to 2398000 hectares, of which about $1,714,000$ hectares were forest land. The forests alone thus cover an area about equal in size to that of the Administrative District of Häme (Tavastehus). In the main, these forests belong to the various branches of the timber industries, having been purchased by the latter during the last few decades in order to ensure their supply of raw material and at the same time to hold prices for raw material at a level favourable to themselves, and otherwise to assure their economical position; in certain cases, also to procure agricultural products for their employees, to facilitate rafting, etc. - The standpoint against land-ownership by this group is based chiefly on social and colonization ideas. A law passed in 1915 restricted the right of Joint Stock Companies to own land, and another law has recently been discussed by the Diet for the expropriation of lands procured against the stipulations of the former law, while the proposed law regarding the procuring of land for colonization purposes will, in practice, be largely directed towards the Joint Stock Company lands.

The forests of the Companies stand as a rule on a higher economical plane than the average private forest. The Companies employ numerous forest superintendents with a higher forestry education and also foremen who have passed through the forestry schools. Many of the Companies have had regular working plans drawn up for their forests. - The care of the Companies' forests is in no greater degree subject to the law than that of private forests.

In this connection, it may be mentioned that the State owns the majority of shares in two of the greatest firms engaged in the timber industries, viz., O. Y. Tornator and A. B. Gutzeit \& $C: O$.

\section{Private Forests.}

The only law restricting the exploitation of private forests is that of 1917, which forbids such cutting of forest, or the leaving of forest land in such condition, that the natural regeneration of a forest is endangered. The cutting of young growing foreśt otherwise than by thinning is also forbidden. The surveillance of this law has been dealt with earlier. The breaking of these stipulations brings with it the enforced protection of the forests against cutting and the reafforesting of the area. For the facilitating of control in this respect, the forest-owner is obliged to send in a list of the proposed cuttings, before these are begun, to the Parish Forestry Committee, unless the forest is managed according to a plan approved by the District Forest Committee.

The District Forestry Committees commenced their activities in 1918. As far as this was rendered possible by the state of war in the first half of the year, the work done was of an organizatory nature. 
From the years 1919 and 1920 a few numerical statements may be given. It is, however, to be remarked in connection with these, that the increase in the later figures compared with the preceding year is due chiefly to the fact that the activities of the Parish and District committees did not everywhere attain their full scope until 1920.

Number of applications for cutting .........

Area reported for cutting, in hectares........

Number of timber-trees reported for cutting Cubic contents of smaller trees reported for

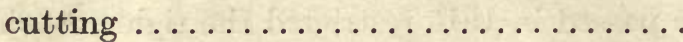
Number of protection-orders ............ Area ordered for protection, in hectares ....

8,199272

2886522

185

5447
16,905650

7966750

336

13832

For the furthering of professional knowledge of silviculture amongst private landowners, the so-called Silvicultural Societies were formed, which for the service of their members employ a joint forestry foreman and in certain circumstances even a professional forest superintendent. The most considerable of these societies is at present in South-west Finland, the Swedish-speaking "Sydvästra Finlands privatrevirförbund", which comprises four different areas, each with its own superintendent, the total area being about 25000 hectares of forest.

Also certain of the large private estates employ professionals, and the forests of these have in many cases been extremely well maned for already a longer period.

Further, during recent years, considerable activities have been planned in connection with the idea of co-operation in forest-management. A company called the "Metsänomistajien Metsäkeskus O. Y." (Forest-owners' Forest Central) has been established, covering the whole country, the aim of which is the mediation for sale and the refining in the company's own works of the timber grown by members, and the establishing of direct relations with timber buyers abroad. For the present, its endeavours are directed chiefly to the formation of local co-operative societies as members in the larger central, many such having already been formed. Certain have even commenced an extremely lively activity.

\section{Outside Forestry Enlightenment=work.}

For the improvement of private silviculture a society called "Suomen Metsänhoitoyhdistys Tapio" was established as a central organization for this work. It includes among its members 22 agri- 


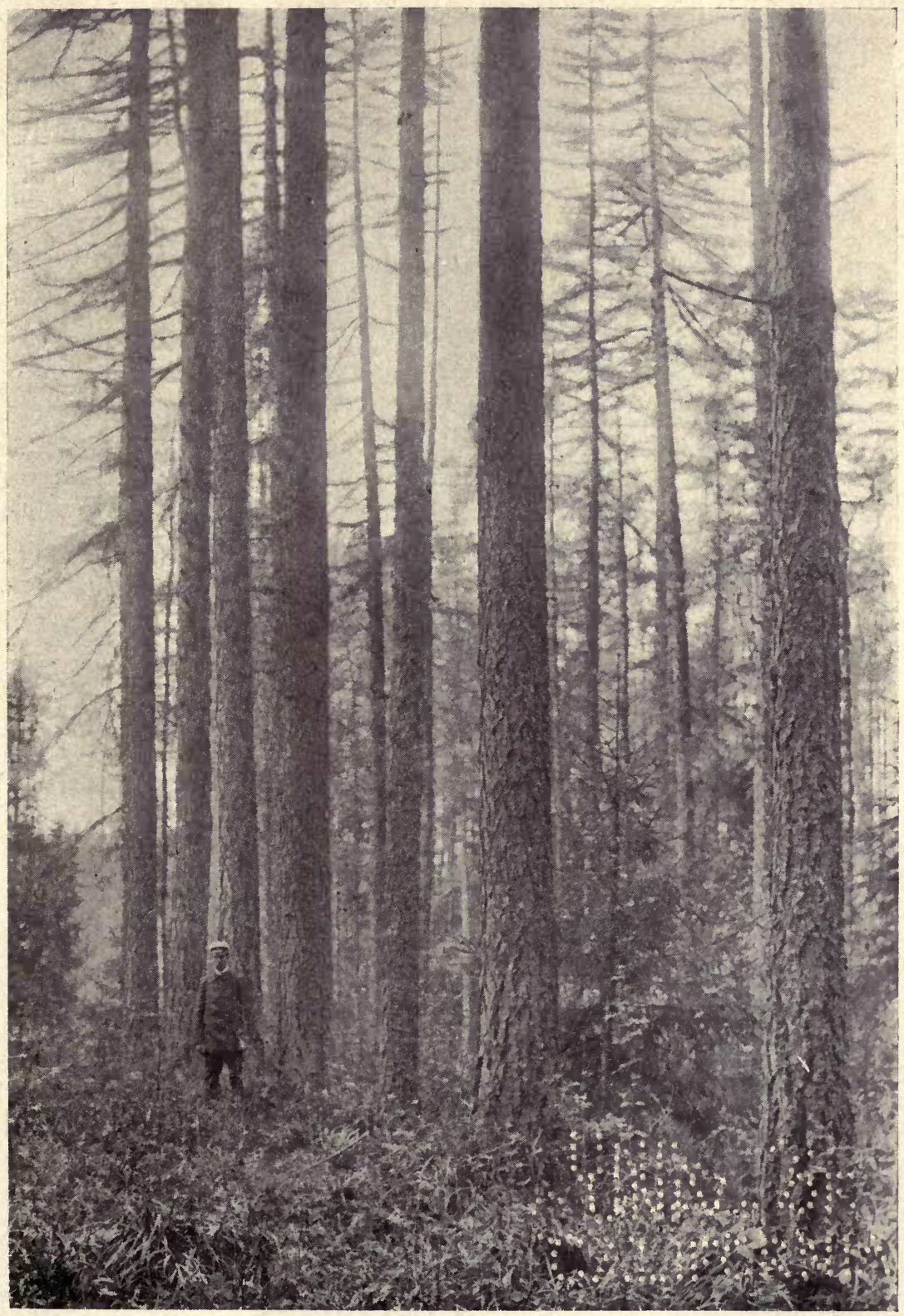

Stand of larch (Larix sibirica) in South Finland. 

cultural societies, and 400 (in 1921, 458) smaller local forest and agricultural societies. The Tapio Society publishes its own periodical, the "Tapion, of which a condensed Swedish edition appeared earlier under the title "Uppsatser $i$ skogsbruk», and also other forestry literature, assists the agriculturel societies in the part of their work relating to silviculture, arranges meetings, excursions and advisory courses, collects and publishes statistics regarding private forests and draws up the annual reports of the forestry activities of the societies which obtain State subsidies for the purpose. The "Tapio» has its own nurseries and seed-kiln, and takes part otherwise in the trade of plants and seeds. The State subsidy allowed the "Tapio" for 1922 rose to 75,000 marks. - The actual local advisory and guidance work is done through the agency of the 22 agricultural societies which employ professional forest superintendents and foremen who have passed through the forestry schools. These societies receive annually, among other grants, a certain sum specially for the spreading of forestry. - An idea of the proportions of the "Tapio» and its member-societies is given by the following.

The number of members in the societies forming the "Tapio" was:

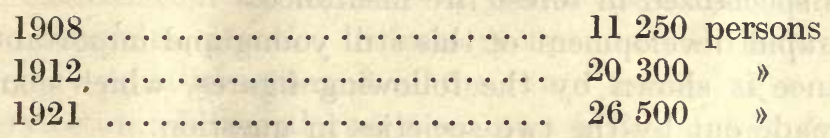

In the year 1921, the agricultural societies employed 13 forest superintendents as forestry experts and 32 forestry-foremen as advisers. The number of these officials was much greater before the war: e.g., 18 of the former and 48 of the latter in 1912. During the years 1911 - 1914, when activity was at its highest, the annual number of official acts executed by them varied between $9000-10000$.

The central organization for co-operative work in Finland, the "Pellervo-Seura" has also included co-operation in forestry in its programme. For the purpose, it possessed earlier a special Forest Office, which has now, however, been abolished.

Acting chiefly among professional silviculturalists, there are the "Suomen Metsänhoitoyhdistys" (Finnish Silvicultural Society), established in 1877 and the comparatively much younger "Yksityismetsänhoitajayhdistys" (Private Foresters' Society). Together with the "Suomen Uittajainyhdistys" (Society of Finnish Timber-floaters) the two latter publish a silvicultural magazine, "Metsätaloudellinen Aikakauskirja». The forestry-foremen have also their own society and magazine, "Metsämies". For the improving of private silviculture in the Swedish-speaking districts there is the »Föreningen för skogs- 
kultury Society, and for similar purposes, certain of the agricultural periodicals in the Swedish language contain a special forestry department.

The State subsidies in $\mathbf{1 9 2 2}$ for the agricultural and silvicultural societies for work in the service of silviculture totalled 865000 marks. For the sake of comparison it may be mentioned that the grants for agriculture total 2911200 marks and for the development of cattlefarming an additional 1772725 marks.

A very important factor in the field of forestry in Finland is the fire-insurance of forests. Forestfires are an annual source of considerable loss to our forest-owners. And further, forest-insurance is essential for the regulation of the question of credit againt forest. Fire policies are granted by two mutual insurance societies: the "Sampo» at Turku (Abo) and the "Suomen Metsänomistajain Keskinäinen Metsäpaloapuyhdistys" (Finnish Forestowners Mutual Forest Fire Aid Society) in Helsinki (Helsingfors). Another concern, the Maanviljelijäin Vakuutusosakeyhtiö Terra" was in action for a couple of years, but has now ceased to exist. The "Sampo" makes out policies in many different branches. Its "Forest Department" was added in 1914. The other Society, established in 1916, has specialized in forest fire insurance.

The rapid development of this still young and important branch of insurance is shown by the following figures, which contain the policies made out by the two societies in question.

Total area of
Year
forest insured
against fire in
thousands
bectares

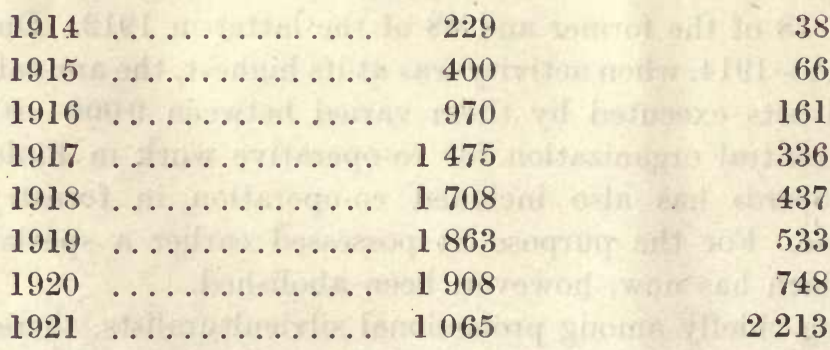

Amount of
insurance in
millions marks

38

66

161

336

437

533

748

213

\section{Education in Forestry and Scientific Investigation.}

For education in elementary forestry the State has provided five' schools of forestry. Four of these schools are held in the Finnish language: the Evo (at Lammi), Tuomarniemi (at Ätsäri), Nikkarila (at Joroinen) and Rovaniemi forestry schools. The fifth, situated at Tammisaari (Ekenäs) is held in the Swedish 
langnage. The course gone through at the latter was previously extended over one year, but according to a regulation issued this year, it will now be a two-year course, as is the case with the other, Finnish schools. For entrance, elementary school education is demanded. The teaching comprises practical forestry work and sufficient theory for the pupils to understand the former. The intention of the schools is the forming of a class of expert forestry foremen, for which the State, the forest industries, agricultural societies, forestry societies, co-operative forest associations and the owners of large private forests have found increasing employment. Latterly, the schools have turned out 70 - 80 forestry foremen each year. - In the autumn of 1921, the first term in the Finnish Sawmills Industries School was begun, a school kept up partly by the State and partly by private subscription. It contains two separate departments: one for turning out foremen for the sawmills, the other for forestry and rafting foremen. The course lasts one year. This school has long been needed, as the lack, particularly of trained sawmill foremen has been very great.

$\mathrm{Higher}$ education in forestry has since 1908 been given at the University of Helsinki (Helsingfors), after the closing of the Evo School of Forestry. The average duration of study for the forestry examination averages 3-4 years. Besides theoretical studies, two summers, practice in forestry is enforced, the work for the latter being specially arranged in the State forests. For permanent State service an additional year's practice is demanded after the examination. Degrees can be taken at the University with silviculture and forest management as chief subjects, doctor's degrees even, which latter has proved extremely fruitful from the point of view of scientific investigation in forestry.

A forest research institute was established in Finland in 1917. It is kept up by the State, its purpose being the study of questions important for forest economy by scientific methods, whose application by private individuals would for one reason or other be extremely difficult, if not altogether impossible. The institution is divided into three sections, each with its own special branch of work, viz., silviculture, forest management and the science of soils. Each section is directed by a professor, of whom the same qualifications as those for university professorship are demanded, and in addition, experience in practical forestry, in order that he should be able to judge rightly the practical value of the various investigations that crop up. Each section has further one assistant. The results of investigations are published in a series: "Metsätieteellisen Koelaitoksen julkaisuja, Communicationes ex Instituto questionum forestalium Finlandiae editael, of which four volumes have hitherto appeared. 
For the support of individual forestal investigation and as a link between investigators, a society was formed already in 1909, "Suomen Metsätieteellinen Seura» (Finnish Forest Society), the publications of which, Acta forestalia fennica, now total 21.

\section{The Significance of the Forests for Finland's Industries and the Trade Balance.}

A great part of the industries of Finland is based on its wealth of forest. The sawmills, veneer, bobbin, box, furniture and other factories, which obtain their raw material from the forests, are extremely numerous. The paper industries, which have developed in the space of twenty or thirty years into one of the most important branches of industry in the country, use but little other fibre than that obtained from wood. The wallpaper, paper-bag and envelope industries thrive, on their part, in the shelter of the paper factories.

Twine and cloth of paper are modern offshoots of these industries, with perhaps a promising future before them. Comparatively little attention has as yet been paid to the dry distillation of wood, but this should also possess great possibilities of development: the production of tar, turpentine, wood alcohol, acetic acid etc., can be greatly increased.

The number of sawmills is slightly over 600 . Their combined production of sawn timber during the last few years before the worldwar was $7000000-900000$ standards annually. The war affected production unfavourably, but this is at present rapidly rising again. In 1920 there were 25 wood-pulp factories in Finland, their yearly output being about 110000 tons, 24 cellulose factories (annual output about 300000 tons) and 31 paper factories (annual output about 220000 tons).

A good third of the industrial workers of the country depend for their living on these industries. Similarly, the value of their production is about one third of the gross production of our combined industry. - The timber industries are the most independent of all Finnish industries. E.g., in 1916, of the total value of the raw material and half-completed products needed by them, only $0.6 \%$ came from abroad. The corresponding figure in the paper industries was $21.7 \%$, against $71.8 \%$ in the textile industries, $78.2 \%$ in the food and luxuries industries, $69.4 \%$ in the engine-shops, and $50.3 \%$ in the total industries.

The forest industries of Finland depend chiefly on their export, and on the other hand, the export of more or less worked forest products decides the condition of our trade balance. Fig. 9 shows 
the division of the value of our export among different classes of goods. The wood-pulp paper export certainly includes also paper from linen rags, which are not forest products. But their effect on the whole is very small. On the other hand, the products of the dry distillation of wood are included among "other goods."

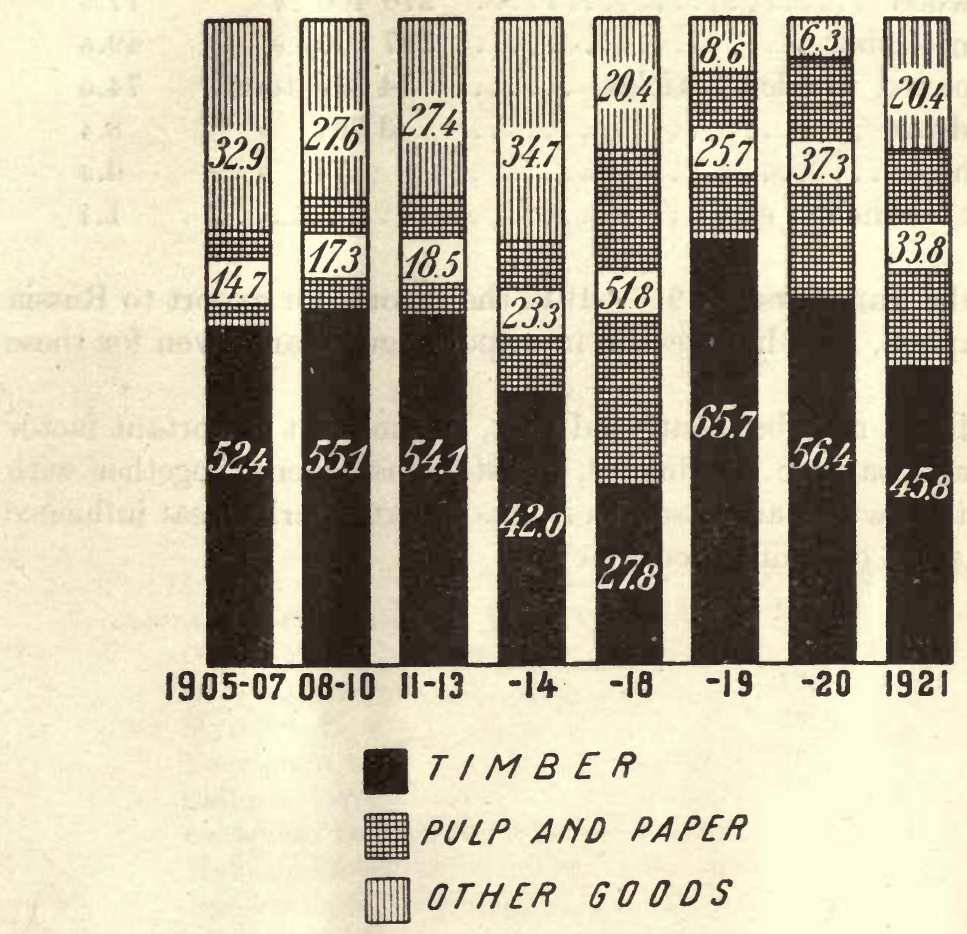

Fig. 9.

Division of the value of export among the different groups of goods.

The development of the amounts and values of the export of forest products is shown by the following figures, which for the years from 1907 to 1910 are given in averages for five-year periods.

\begin{tabular}{|c|c|c|c|c|c|c|}
\hline \multirow{2}{*}{ Year } & \multicolumn{2}{|c|}{ Sawn timber } & \multicolumn{2}{|c|}{$\begin{array}{l}\text { Wood-pulp, mech- } \\
\text { anical + chemical }\end{array}$} & \multicolumn{2}{|c|}{$\begin{array}{l}\text { Cardboard, paper } \\
\text { and completed } \\
\text { paper articles }\end{array}$} \\
\hline & $\begin{array}{c}1000 \\
\text { cub. m. }\end{array}$ & $\begin{array}{l}\text { mill. } \\
\text { marks }\end{array}$ & tons & $\begin{array}{l}\text { mill. } \\
\text { marks }\end{array}$ & tons & $\begin{array}{l}\text { mill. } \\
\text { marks }\end{array}$ \\
\hline $1901-1905$ & 2603 & 92.1 & 41675 & 4.7 & 76305 & 22.2 \\
\hline $1906-1910$ & 2914 & 109.3 & 67764 & 10.8 & 121824 & 32.6 \\
\hline $1911 \ldots \ldots$ & 3159 & 132.0 & 114247 & 15.5 & 168327 & 42.5 \\
\hline $1912 \ldots$ & 3429 & 134.5 & 138234 & 19.5 & 183294 & 45.4 \\
\hline $1913 \ldots \ldots \ldots$ & 4219 & 175.9 & 126508 & 18.5 & 200606 & 52.8 \\
\hline $1914 \ldots \ldots \ldots$ & 1765 & 74.7 & 96998 & 15.0 & 184484 & 50.8 \\
\hline $1918 \ldots$ & 269 & 22.1 & 93466 & 50.0 & 31263 & 47.2 \\
\hline 1919 ..... $\ldots \ldots$ & 2767 & 475.7 & 138195 & 99.0 & 62037 & 118.6 \\
\hline $1920 \ldots \ldots \ldots \ldots$ & 3483 & 1322.9 & 192526 & 431.3 & 170633 & 625.5 \\
\hline $1921 \ldots \ldots$ & 2936 & 1257.1 & 191593 & 458.3 & 132028 & 608.7 \\
\hline
\end{tabular}


In addition to the foregoing, considerable quantities of other forest products were exported e.g., in 1921:

$$
\text { Quantity }
$$

Unprepared timber .......... $589700 \mathrm{~m}^{3}$

Fuelwood

Hewn timber

270400 "

197100 "

Completed wooden articles

Wood-tar

Resin

14330 tons

3767 "

74 》)
Value, mill. mks.

77.9

17.9

49.6

74.0

8.4

0.4

1.1

Bark, branches etc.

For the war years of 1915-1917 the reports for export to Russia are incomplete, for which reason no export figures are given for these years.

Finally, it may be mentioned that, as the most important factor in the trade balance of Finland, forest management, together with the industries which are based on it, has a particularly great influence over the state of Finnish currency. 


\section{Errata.}

Page 7. The figures for Savo and Karelia in the lists showing the relative percentage of the various forest-types should be:

Oxalis-Majanthemum type ......... $2.92 \%$

Oxalis-Myrtillus type $\ldots \ldots \ldots \ldots \ldots$ 17.85 ,

Myrtillus type ............. 28.68 ,

Vaccinium type $\ldots \ldots \ldots \ldots \ldots \ldots \ldots, 32.35$,

Calluna type ................ 12.91 "

Geranium-Dryopteris type ....... 0.42 ,

Hylocomium-Myrtillus type ....... 4.28,

Empetrum-Myrtillus type ......... 0.42 ,

Cladina type $\ldots \ldots \ldots \ldots \ldots \ldots \ldots .0 .17$, 

Photomount

Pamphlet

Binder

Gaylord Bros., Inc.

Makers

Stockton, Calif

PAT. JAN. 21, 1908

THE UNIVERSITY OF CALIFORNIA LIBRARY 


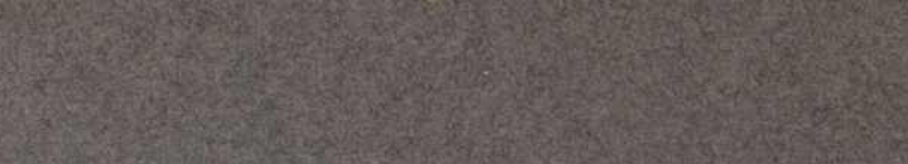

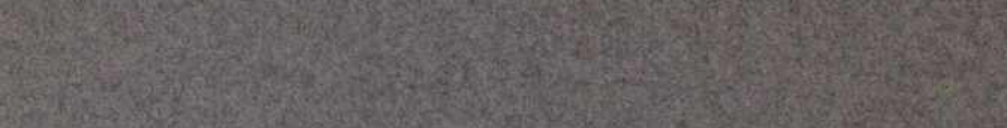

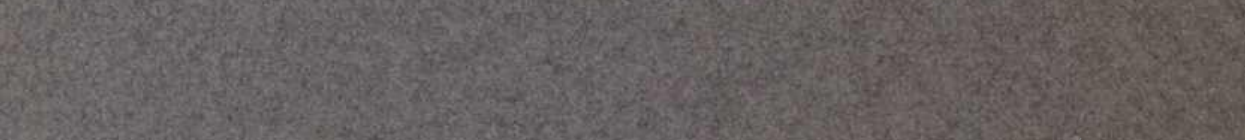

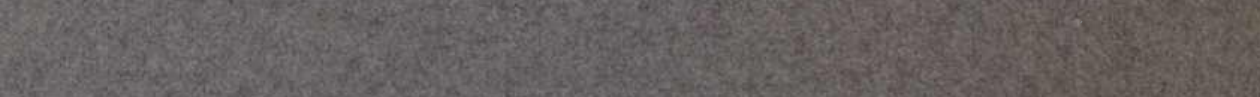

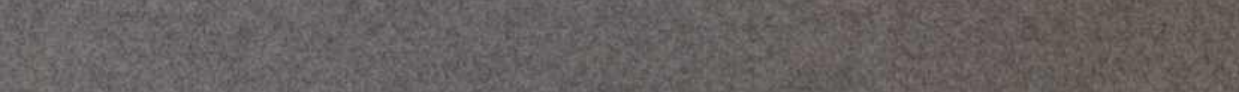

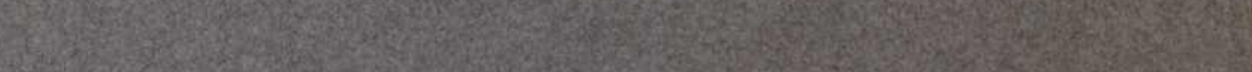

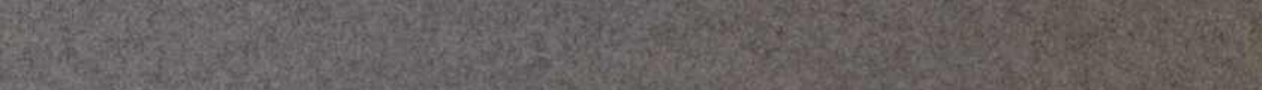

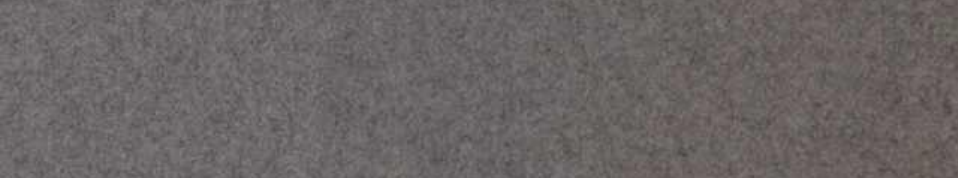

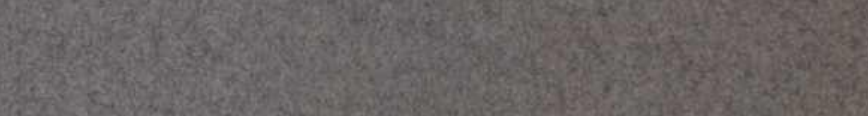
Q3.

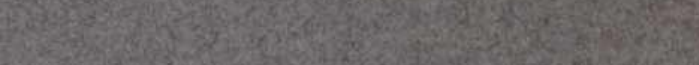

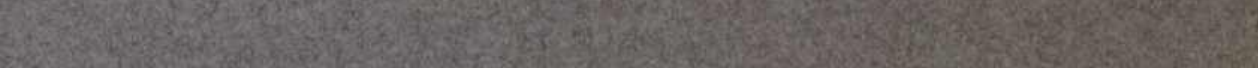

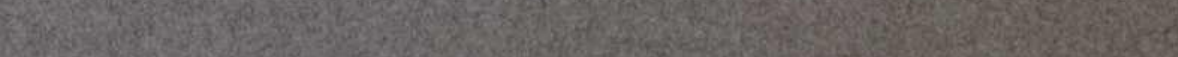

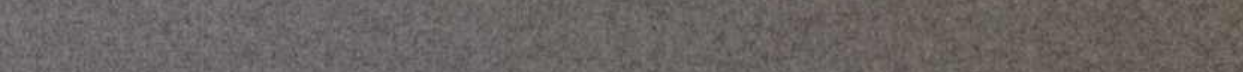

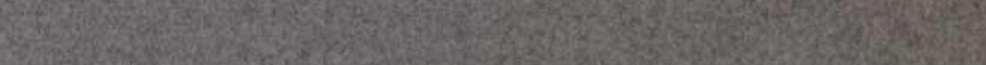
What

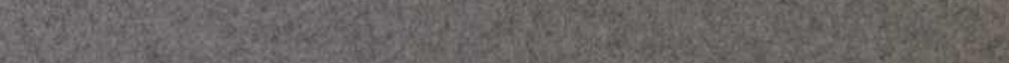

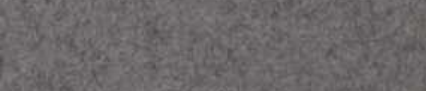

6.

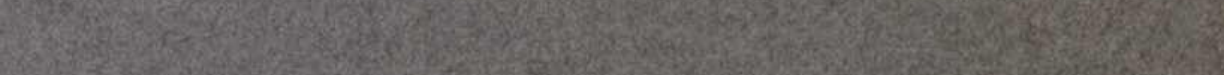

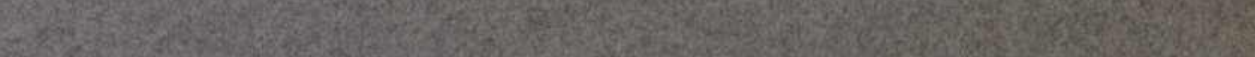

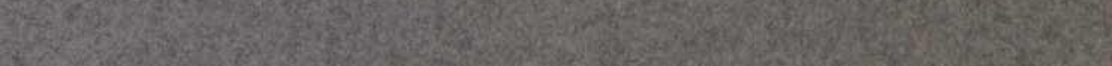

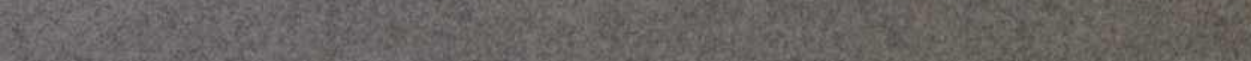
2.5.

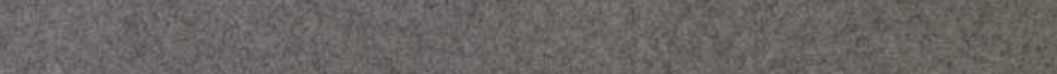

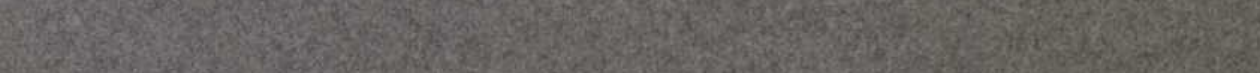

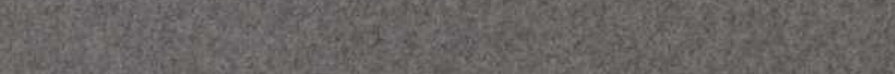

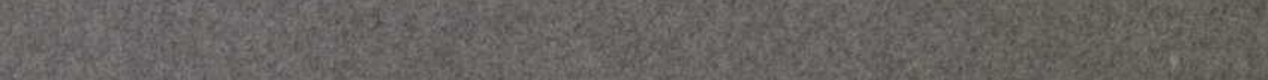
H.

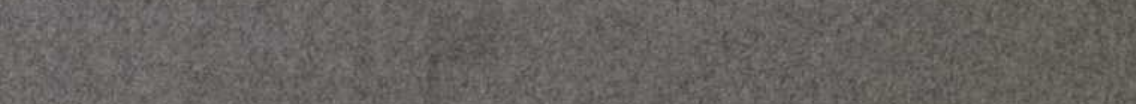

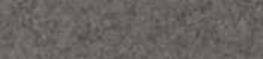

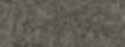

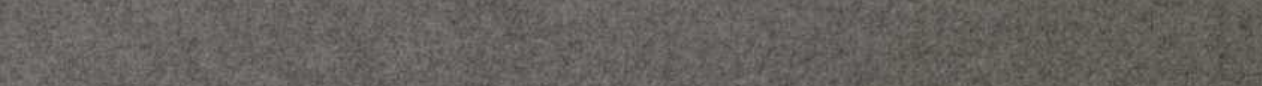

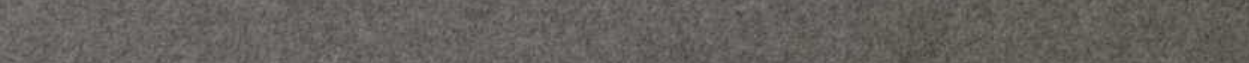

